\title{
Estradiol for the mitigation of adverse effects of androgen deprivation therapy
}

\author{
Nicholas Russell1,2, Ada Cheung, ${ }^{1,2}$ and Mathis Grossmann 1,2 \\ 1Department of Endocrinology, Austin Health, Heidelberg, Victoria, Australia \\ 2Department of Medicine (Austin Health), The University of Melbourne, Heidelberg, Victoria, Australia
}

Correspondence should be addressed to $N$ Russell

Email

nicholas.russell@austin.org.au

\begin{abstract}
Prostate cancer ( $\mathrm{PCa}$ ) is the second most commonly diagnosed cancer in men. Conventional endocrine treatment for PCa leads to global sex steroid deprivation. The ensuing severe hypogonadism is associated with well-documented adverse effects. Recently, it has become apparent that many of the biological actions attributed to androgens in men are in fact not direct, but mediated by estradiol. Available evidence supports a primary role for estradiol in vasomotor stability, skeletal maturation and maintenance, and prevention of fat accumulation. Hence there has been interest in revisiting estradiol as a treatment for $\mathrm{PCa}$. Potential roles for estradiol could be in lieu of conventional androgen deprivation therapy or as low-dose add-back treatment while continuing androgen deprivation therapy. These strategies may limit some of the side effects associated with conventional androgen deprivation therapy. However, although available data are reassuring, the potential for cardiovascular risk and pro-carcinogenic effects on PCa via estrogen receptor signalling must be considered.
\end{abstract}

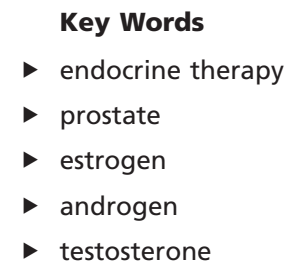

Endocrine-Related Cancer (2017) 24, R297-R313

\section{Introduction}

Prostate cancer (PCa) is the second most commonly diagnosed cancer in men, after lung cancer. Worldwide it is responsible for $7 \%$ of all deaths in men, making it the fifth leading cause of male cancer death (globocan.iarc.fr). There is high inter-country variability in prevalence, with less variation in attributable mortality (Bourke et al. 2013), due to differences in rates of prostate-specific antigen testing, with typically higher rates in more developed countries.

Androgen deprivation therapy (ADT) has been a cornerstone of PCa management since the 1940s. A variety of approaches have been used: bilateral orchiectomy; high-dose oral or parenteral estrogens; luteinizing hormone-releasing hormone (LHRH) agonists (LHRHa); LHRH antagonists; androgen receptor (AR) antagonists, and extragonadal androgen synthesis inhibitors. LHRHa are the main form of ADT in current use and nearly 50\% of men with PCa can expect to undergo this treatment (Bourke et al. 2013).

With improving survival rates for $\mathrm{PCa}$, and the recognition that most men with $\mathrm{PCa}$ do not die from it (Lu-Yao et al. 2004), there has been considerable focus on the metabolic side effects of long-term LHRHa. Men receiving this treatment experience constitutional symptoms and vasomotor symptoms (VMS), bone structural deterioration and fractures, a tendency to sarcopaenic obesity and insulin resistance, and subtle cognitive and mood changes (Grossmann \& Zajac 2011).

LHRHa cause global sex steroid deprivation, with near-undetectable levels of both androgens and estrogens

Published by Bioscientifica Ltd 
within 30 days of administration (Sharifi et al. 1996). A growing body of basic scientific and clinical studies has now clearly demonstrated that many of the biological actions of testosterone in men are mediated by its metabolite, $17 \beta$-estradiol $\left(\mathrm{E}_{2}\right)$. Loss of $\mathrm{E}_{2}$ signalling appears to be primarily responsible for certain components of the male hypogonadal syndrome such as vasomotor instability, bone deterioration and fat gain (Finkelstein et al. 2013, 2016, Taylor et al. 2016).

This review will discuss the role of estrogens in the endocrine treatment of PCa. While estrogens have been used extensively in the past as a mode of ADT, they have been replaced in current practice with LHRHa because the latter have been considered a safer and better tolerated alternative. Advances in the understanding of the biological importance of $E_{2}$ in men have prompted a recent resurgence of interest in using $\mathrm{E}_{2}$ in men with PCa either as an alternative to LHRHa, or as low-dose replacement therapy in addition to LHRHa. Widespread clinical adoption of such strategies will require convincing evidence that estrogens can be used without the adverse cardiovascular impact of earlier regimens, and that such use will not have pro-carcinogenic effects.

The material presented is based on peer-reviewed journals indexed on the PubMed database from 1940 to May 24, 2017, using the following search terms: prostate cancer, androgen deprivation therapy, hypogonadism and estradiol. Studies were limited to those published in English and studies in men. In addition, pertinent review articles were searched for additional publications, and relevant articles were selected.

\section{Past and present endocrine treatments for prostate cancer}

In 1941, Huggins and Hodges published evidence that orchiectomy orinjection of estrogens (stilbestrolorestradiol benzoate) caused regression of metastatic PCa in men, while testosterone injections promoted growth (Huggins \& Hodges 1941, Huggins 1967). On the strength of this work, and a large retrospective observational study that reported better survival in men receiving endocrine treatment (Nesbit \& Baum 1950), orchiectomy and oral diethylstilbestrol (DES) became standard treatments for PCa. Orchiectomy works by surgical removal of the predominant source of testosterone production, while DES exerts ER-mediated negative feedback on pituitary gonadotrophs, resulting in hypogonadotropic hypogonadism. Estrogens also directly inhibit testicular testosterone production (Melner \& Abney 1980) associated with morphological changes in Leydig cells (Leavy et al. 2017). DES has additional pharmacologic anti-cancer effects such as antagonism of androgeninduced telomerase activity in PCa cell lines (Geier et al. 2010).

A series of retrospective randomized controlled trials (RCTs) were performed by the Veterans Administration Cooperative Urological Research Group (VACURG) in the 1960s (Byar 1973). These trials compared various doses of DES (0.2-5 mg) with placebo in localized PCa after radical prostatectomy, and in metastatic disease. The VACURG studies demonstrated efficacy of DES on PCa outcomes at the expense of increased cardiovascular morbidity and mortality at higher doses. This helped to define a role for oral DES $(1-3 \mathrm{mg})$ in symptomatic locally advanced or metastatic disease (Torti 1984).

The dose-dependent elevation in cardiovascular mortality caused by oral estrogen was due to an increase in myocardial infarction, stroke, ischaemic cardiomyopathy and pulmonary embolism (Byar 1973). This effect was shown to be associated with elevations in blood pressure and adverse alterations in hepatic metabolism of clotting factors, lipids and other proteins (Schoultz et al. 1989). As will be discussed in the 'Potential adverse effects of estrogen therapy' section, these problems might be largely avoided with parenteral administration of non-synthetic estrogens.

LHRH was discovered in the early 1970s (Schally et al. 1971) and in the context of safety concerns about estrogens, leuprolide (Leuprolide Study Group 1984) and subsequently other depot LHRHa (Seidenfeld et al. 2000) were shown to be non-inferior to orchiectomy or DES in men with metastatic PCa with respect to PCa outcomes. In comparison to high-dose synthetic oral estrogens, LHRHa had the advantage of relative cardiovascular safety and less gynaecomastia, at the significant cost of more VMS and osteoporosis (Leuprolide Study Group 1984, Ockrim et al. 2006, Hedlund et al. 2008). These side effects ensured that interest in estrogen as an alternative continued.

Large RCTs of intramuscular polyestradiol phosphate (PEP), with median follow-up period of over 10 years, showed no overall mortality or cancer-specific survival difference compared with combined androgen blockade (CAB) (Hedlund et al. 2008) or orchiectomy (Mikkola et al. 2007). However, both the SPCG-5 trial (Hedlund et al. 2008) and the Finnprostate 6 study (Mikkola et al. 2007) demonstrated more cardiovascular morbidity in the PEP arm, without excess cardiovascular mortality in patients with metastatic disease. However, in the Finnprostate 6 study, patients with locally advanced disease did experience a higher risk of cardiovascular death (RR 3.52;

Published by Bioscientifica Ltd 
95\% CI 1.65-7.54; $P=0.001$ ) (Mikkola et al. 2007). The Prostate Adenocarcinoma TransCutaneous Hormones (PATCH) trial was a phase II single- (investigator only-) blinded RCT designed to assess safety and efficacy of high-dose transdermal $\mathrm{E}_{2}$ vs LHRHa in men with locally advanced or metastatic ADT (Langley et al. 2013). PATCH was reassuring with respect to cardiovascular safety, and a phase 3 study has commenced.

Most commonly used ADT modalities in current practice are LHRHa, LHRH antagonists, and much less frequently in developed countries, orchiectomy. ADT has an established role as first-line therapy in metastatic PCa where it provides symptomatic benefit (Pagliarulo et al. 2012). ADT in various durations (commonly 6 months to 3 years) is combined with definitive radiotherapy for localized intermediate- and high-risk disease and for locally advanced disease. In these settings, ADT has been shown to improve survival rate (Cornford et al. 2017, Mottet et al. 2017). ADT is also used in the adjuvant or salvage setting for biochemical recurrence following radical prostatectomy (with or without radiotherapy) although no survival advantage has been demonstrated in this context (Pagliarulo et al. 2012, Cornford et al. 2017, Mottet et al. 2017). For metastatic PCa, ADT is generally prescribed indefinitely, although intermittent therapy may be used.

Traditional antiandrogens such as bicalutamide are not as effective as LHRHa as monotherapy, and their addition to LHRHa as CAB has not demonstrated a consistent survival benefit (Seidenfeld et al. 2000). However, more effective AR blockers such as enzalutamide have survival benefits in castrate-resistant prostate cancer (CRPC), providing clinical proof of principle that CRPC remains androgen-dependent (Scher et al. 2012, Beer et al. 2014). This is also evidenced by the survival benefit reported with abiraterone, a CYP17 inhibitor which inhibits adrenal and intra-tumoural androgen synthesis in LHRHa-treated patients (de Bono et al. 2011, Ryan et al. 2013).

\section{Side effects of androgen deprivation therapy}

Side effects of non-estrogen modes of ADT have been reviewed (Sharifi et al. 2005, Grossmann \& Zajac 2011, Collins \& Basaria 2012, Cheung et al. 2014) and will only be briefly outlined. There is a justified focus on such side effects, particularly because prolonged survival is expected in most men in whom this therapy is used. Overall, PCa has a low case fatality rate, and most men diagnosed with PCa will die of another condition (Lu-Yao et al. 2004, Albertsen et al. 2011). Cardiovascular disorders are responsible for at least a quarter of deaths in men with PCa (Lu-Yao et al. 2004). For localized (T1c or T2), moderately and poorly differentiated PCa managed conservatively, PCa-specific 10-year survival is 73-98\% (Albertsen et al. 2011). For men treated with adjuvant ADT following radical prostatectomy for high-risk localized disease, 5-year overall survival rate is over 95\% (Dorff et al. 2011). For men who have developed CRPC, median survival was 2-3 years, even prior to widespread use of novel antiandrogens which have been shown to prolong survival (de Bono et al. 2011, Scher et al. 2012).

\section{Constitutional, vasomotor and sexual symptoms}

LHRHa are associated with fatigue, anaemia, loss of libido, VMS and possibly detrimental effects on mood and cognition (Grossmann \& Zajac 2011). Fatigue is likely to be multifactorial. Androgen ablation produces a mild normocytic anaemia, with haemoglobin and haematocrit within the female normal range (Grossmann \& Zajac 2012). Hot flushes are experienced by approximately 70-80\% of men undergoing non-estrogen-based ADT (Karling et al. 1994, Sharifi et al. 2005). They are often mild and abate, but may persist and be severe enough to warrant pharmacotherapy (Karling et al. 1994, Sharifi et al. 2005, Jones et al. 2012). Hot flushes may interfere with sleep and, along with other side effects of ADT, reduce quality of life (Cheung et al. 2016). Men undergoing ADT generally experience loss of libido, erectile dysfunction and reduced sexual activity (Grossmann \& Zajac 2011). Men frequently report an associated perceived loss of masculinity and reduced relational intimacy (Donovan et al. 2015).

\section{Bone loss}

LHRHa or orchiectomy lead to accelerated bone turnover and rapid bone density decline, microarchitectural deterioration, and increased fracture risk. In the first year of ADT there is an increase in bone turnover and a 5-10fold increase in the rate of areal BMD loss (Greenspan et al. 2005). Areal BMD measured by dual-energy X-ray absorptiometry (DXA) underestimates the degree of cortical BMD loss and microarchitectural deterioration in cortical and trabecular compartments (Hamilton et al. 2010). There is a lack of prospective studies reporting fracture rates in men undergoing ADT (Diamond et al. 2004). Large retrospective studies report higher fracture rates in these men (Shahinian et al. 2005, Shao et al. 2013) and fracture post ADT was associated with a 10\% 12-month mortality (Shao et al. 2013). Increased fracture risk is likely to reflect the BMD decrement, deterioration in

Published by Bioscientifica Ltd. 
microarchitecture and declines in muscle function possibly contributing to falls (Cheung et al. 2017).

\section{Sarcopaenia, obesity and physical function}

Men commencing LHRHa lose lean body mass and gain fat mass. Total body fat mass increases by about $10 \%$ during the first year (Smith et al. 2002a, Greenspan et al. 2005, Spry et al. 2013) but whether visceral fat mass increases remains controversial (Grossmann et al. 2013). Lean body mass decreases during the first year of ADT. However, the lack of adequate controls in many longitudinal studies makes it difficult to distinguish the magnitude of the ADT effect from that of ageing alone or cancer itself (Cheung et al. 2014). In one appropriately controlled study, there was a significant 12-month lean body mass decline of $3.5 \pm 0.5 \%$ in men newly commencing nonestrogen ADT (Greenspan et al. 2005). Effects occur early and appear to plateau after 6 months of ADT. In the lower limb, LHRHa therapy may cause selective decrements in quadriceps, soleus and iliopsoas function and was associated with emergent gait broadening and decline in gait speed at 12 months (Cheung et al. 2017) but whether ADT itself causes falls has not been rigorously studied.

\section{Insulin resistance, dyslipidaemia and cardiovascular risk}

Causal links between sarcopaenia and metabolic alterations that enhance cardiovascular risk have been uncovered in recent years (Basaria \& Bhasin 2012, Boström et al. 2012, Guridi et al. 2015). It is likely that ADT-induced sarcopaenic obesity is responsible for the increase in insulin resistance observed with ADT (Smith et al. 2006), but there may be body composition-independent effects of sex steroid deficiency, either directly mediated by low testosterone, and/or because of low $\mathrm{E}_{2}$ (Grossmann et al. 2013). ADT is also associated with increased triglycerides, increased total cholesterol, and reductions in high-density lipoprotein (HDL)-cholesterol (Grossmann \& Zajac 2011). In some large observational studies, there is an increase in the incidence of diabetes and of cardiovascular events in men undergoing ADT, but there are contradictory conclusions in other studies, and causal relationships have not been established (Collins \& Basaria 2012).

\section{Mood and cognition}

Evidence for the cognitive effects of ADT is limited. AR and ER are abundant in the prefrontal cortex, amygdala and hippocampus (Beer et al. 2006). Animal studies indicate important roles for testosterone and $\mathrm{E}_{2}$ in memory and learning but human studies have generally been small and have reached mixed conclusions. Studies in men undergoing ADT have also reported contradictory results (Donovan et al. 2015). A systematic review of small observational controlled studies concluded that ADT appears to have subtle negative effects on specific limited cognitive domains such as visuospatial abilities and executive functioning (Nelson et al. 2008). An ADT-related decline in visuomotor task performance is also supported by a subsequent meta-analysis of 14 studies enrolling a total of 417 patients treated with ADT (McGinty et al. 2014). The included studies compared cognitive test performance with healthy controls, men with $\mathrm{PCa}$ not undergoing ADT, or individual pre-ADT baselines. Although available evidence does not suggest that ADT causes global cognitive dysfunction, the small sample sizes in studies to date preclude exclusion of negative effects of ADT in other cognitive domains (Donovan et al. 2015). These impacts need to be confirmed in larger longitudinal controlled studies that attempt to adjust for the influence of other side effects of ADT that may affect cognition, for example, effects on mood and fatigue.

Observational studies report a high prevalence of depressive symptoms in men receiving ADT, but this may be due to effects of age, PCa, and comorbidities (Shahinian et al. 2006). In an analysis of over 78,000 men with non-metastatic PCa and without prevalent depression in the SEER database, those who received ADT within 6 months of diagnosis had a 23\% increased risk of incident depression over the following 2.5 years, adjusting for a range of demographic and clinical variables (Dinh et al. 2016). Risk of depression increased with duration of ADT. Although the potential for unrecognized confounding remains, it seems likely that ADT causes more cases of depression. Whether this is a direct effect of medical castration or a result of other physical effects of ADT is unclear (Donovan et al. 2015).

\section{Some major side effects of ADT may be mitigated by estradiol}

Accumulating evidence suggests that in men, many of the biological actions of testosterone are not direct, but are mediated by $\mathrm{E}_{2}$. It follows that side effects of non-estrogen ADT on bone and body composition, vasomotor stability, and brain may be mediated by $\mathrm{E}_{2}$ and not testosterone deprivation. Discerning $\mathrm{E}_{2}$-specific actions in men has

Published by Bioscientifica Ltd 
been challenging, partly because of assumptions that sequelae of hypogonadism are due to androgen deficiency (Khosla et al. 2001, Finkelstein et al. 2013). Furthermore, $50-75 \%$ of circulating $\mathrm{E}_{2}$ in men is derived from extragonadal aromatization of androgens (Longcope et al. 1969, Kelch et al. 1972, MacDonald et al. 1979), meaning that in normal, untreated hypogonadal, and testosterone-treated hypogonadal men, testosterone and $\mathrm{E}_{2}$ concentrations are highly correlated (Lakshman et al. 2010). This has made the individual contributions of testosterone and $\mathrm{E}_{2}$ to male physiology difficult to discern.

$\mathrm{E}_{2}$ acts as a hormone, circulating in blood to act at distant sites, but is also locally produced by aromatase in fat, bone, brain and other tissues (Sasano et al. 1997, Biegon et al. 2010) to act in an autocrine or paracrine fashion. $E_{2}$ is the most potent natural agonist at estrogen receptors alpha $(E R \alpha)$ and beta $(E R \beta)$. ER $\alpha$ and ER $\beta$ are predominantly located in the nucleus where they function as ligand-dependent transcription factors. Membraneassociated forms are responsible for activation of nongenomic pathways (Razandi et al. 2004). Further $E_{2}$ actions are mediated by the G-protein-coupled estrogen receptor 1 (GPER; previously GPR30). $\mathrm{E}_{2}$-mediated activation of GPER leads to activation of cytoplasmic second messenger pathways (Revankar et al. 2005). GPER and membrane-ER activation are mechanisms by which $\mathrm{E}_{2}$ exerts rapid cellular signalling effects and also indirectly modifies transcription of genes that do not contain traditional estrogen response elements (Björnström \& Sjöberg 2005).

Evidence to support an important role of $E_{2}$ deficiency in the pathophysiology of hypogonadism in men has come from five main lines of enquiry: (1) reports of rare cases of individuals with congenital aromatase, AR or ER deficiency; (2) basic investigations of androgen and estrogen action, for example, murine models; (3) cross-sectional and longitudinal populationbased observational studies of the associations between sex hormones and various surrogate or clinical endpoints; (4) studies of the use of estrogens for ADT; and (5) experiments in healthy men, in which shortterm hypogonadism is induced medically, combined with aromatase inhibition and differential add-back of sex hormones, to isolate parts of the hypogonadal syndrome that are T-dependent, $\mathrm{E}_{2}$-dependent or both. Taken together, these lines of evidence support a primary role for $\mathrm{E}_{2}$ in vasomotor stability, skeletal maturation and maintenance, and prevention of fat accumulation (Table 1).
Table 1 Hypotheses for $E_{2}$ add-back in men undergoing non-estrogen ADT.

\begin{tabular}{|c|c|c|}
\hline \multirow{2}{*}{$\begin{array}{l}\text { LHRHa (low testosterone/low } E_{2} \text { ) } \\
\text { Clinical side effect }\end{array}$} & \multicolumn{2}{|c|}{$\begin{array}{c}\text { LHRHa }+\mathbf{E}_{\mathbf{2}} \text { add-back } \\
\text { (low testosterone/normal } E_{2} \text { ) }\end{array}$} \\
\hline & Hypothesis & $\begin{array}{l}E_{2} \text { threshold for } \\
\text { benefit (pmol/L) }\end{array}$ \\
\hline Anaemia & No benefit & - \\
\hline $\begin{array}{l}\text { Bone density and } \\
\text { microarchitectural } \\
\text { deterioration }\end{array}$ & Improved & 40 \\
\hline Fat gain & Improved & 70 \\
\hline Muscle loss & No benefit & - \\
\hline Insulin resistance & Improved & 70 \\
\hline Vasomotor symptoms & Improved & 90 \\
\hline Sexual symptoms & Improved & 40 \\
\hline Cognitive and mood decline & Unknown & $?$ \\
\hline
\end{tabular}

$\mathrm{E}_{2}$, estradiol; LHRHa, luteinizing hormone-releasing hormone agonist.

\section{Effect of estradiol on vasomotor symptoms}

VMS, predominantly hot flushes and night sweats, are experienced by $70-80 \%$ of women during the perimenopause (Jayasena et al. 2015) and a similar proportion of men undergoing ADT (Karling et al. 1994, Sharifi et al. 2005). Rapid estrogen withdrawal appears to mediate flushes in women via an increase in release of neurokinin B, and possibly other mediators, from the hypothalamus (Jayasena et al. 2015). Neurokinin B acts on neurokinin 3 receptors in the hypothalamic median preoptic nucleus, to stimulate heat dissipation effectors such as cutaneous vasodilatation, diaphoresis and coldseeking behaviour (Rance et al. 2013, Jayasena et al. 2015). In perimenopausal and postmenopausal women, estrogen replacement is the most effective pharmaceutical strategy for mitigating hot flushes (Nelson 2004), although an oral neurokinin 3 receptor antagonist recently appears promising (Prague et al. 2017). Topical $\mathrm{E}_{2}$ is effective at applied doses as low as 12.5-25 $\mu$ g daily (Gadomska et al. 2002, Shulman et al. 2002, Simon et al. 2007). However, in hypogonadal men, including those undergoing ADT, the relative roles of androgen and estrogen deficiency to the pathophysiology of hot flushes have only been recently explored.

Finkelstein and coworkers developed an elegant experimental paradigm to distinguish the roles of testosterone deficiency from those of $\mathrm{E}_{2}$ deficiency in the pathogenesis of a range of hypogonadal symptoms and sequelae (Finkelstein et al. 2013). For 16 weeks, LHRHa were administered to a cohort of healthy male volunteers to produce castrate levels of testosterone and $\mathrm{E}_{2}$ before

Published by Bioscientifica Ltd. 
add-back of one of four doses of testosterone gel or placebo, so that serum testosterone concentrations ranged from castrate to slightly supraphysiologic. A control cohort received placebo LHRHa and placebo testosterone gel. A second cohort of men were additionally given an aromatase inhibitor (AI) to clamp $\mathrm{E}_{2}$ at very low levels, independent of testosterone add-back. This design allows isolation of the effect of testosterone to determine physiological effects that are directly testosterone mediated and those that require aromatization of testosterone to $\mathrm{E}_{2}$. It also allows calculation of thresholds for certain effects. The experimental design does not provide for direct observation of the effects of graded $\mathrm{E}_{2}$ add-back in the absence of $\mathrm{T}$. These effects were inferred by directly comparing outcomes between groups receiving the same dose of testosterone replacement, with or without $\mathrm{AI}$, and by linear regression modelling. In these studies, testosterone was measured by immunoassay and $E_{2}$ by mass spectroscopy.

Using this experimental paradigm, $\mathrm{E}_{2}$ deficiency was shown to be the primary stimulus for VMS in men, although testosterone did have some mitigating effect at high levels (Taylor et al. 2016). Overall, men who received AI had more VMS than men who did not. Men with low $\mathrm{E}_{2}$ levels $(<10 \mathrm{pg} / \mathrm{mL} ; 37 \mathrm{pmol} / \mathrm{L})$ experienced more VMS than controls even when serum testosterone levels were supraphysiologic. In men receiving AI, after adjusting for small differences in $\mathrm{E}_{2}$ levels between testosterone gel dose groups, testosterone replacement did not significantly reduce the incidence of VMS compared with placebo gel until a supraphysiologic replacement dose of $10 \mathrm{~g} /$ day. The authors concluded that physiologic levels of androgens do not play a major role in the regulation of VMS.

Clinical studies comparing estrogen to other forms of ADT have shown that men treated with estrogen are less troubled by hot flashes (Spetz et al. 2001, Hedlund et al. 2008, Langley et al. 2013). In SPCG-5, 70\% of men receiving PEP were free of hot flashes compared to $26 \%$ of men receiving CAB. Similarly, in PATCH, $75 \%$ of men receiving $\mathrm{E}_{2}$ and $44 \%$ of men receiving LHRHa were free of hot flashes at 6 months follow-up (Langley et al. 2013). Therefore, with the caveat that none of these studies included a placebo group to account for hot flash prevalence in eugonadal men, avoiding a hypoestrogenic state does not appear to be totally effective in preventing hot flashes.

In the treatment of VMS, small uncontrolled studies of low-dose oral DES (Miller \& Ahmann 1992, Smith 1994) and transdermal $\mathrm{E}_{2}$ patches (Gerber et al. 2000) suggest estrogens might be effective in treating hot flashes in men receiving other, non-estrogen-based forms of ADT. In a double-blind placebo-controlled crossover trial, $1 \mathrm{mg}$ DES was effective in reducing hot flush severity in 14 men after orchiectomy (Atala et al. 1992).

\section{Effect of estradiol on sexual symptoms}

Animal studies suggest an important role for estradiol in male sexual behaviour (Davidson 1969, Ogawa et al. 2000, Wibowo et al. 2011). However, case reports of men with congenital aromatase deficiency have generally reported normal sexual function, and whether there is improvement with estrogen replacement is controversial (Jones et al. 2007). In the context of PCa, better maintenance of sexual function has been suggested in men receiving ADT that is estrogen based (Wibowo et al. 2011), but there have been no prospective randomized trials and firm conclusions cannot be drawn.

In Finkelstein's experiments, changes in libido and erectile function were related to changes in both testosterone and $\mathrm{E}_{2}$ (Finkelstein et al. 2013). However, anastrozole penetrates the blood-brain barrier poorly because it is a substrate for $\mathrm{P}$ glycoprotein-mediated efflux mechanisms (Miyajima et al. 2013). Therefore, brain aromatase inhibition by this agent is expected to be low and Finkelstein's cohort of men with systemic low, normal or high testosterone and low $\mathrm{E}_{2}$ may not have had corresponding low brain $\mathrm{E}_{2}$ levels. Therefore, local, brain-produced $\mathrm{T}$ - and $\mathrm{E}_{2}$-specific physiological effects on measures such as libido, and perhaps erectile function, on which cognitive processes have an impact, are not well characterized. It remains unproven whether $\mathrm{E}_{2}$ would be effective in mitigating these sexual side effects of nonestrogen ADT.

\section{Effect of estradiol on bone}

The reduction in bone density associated with male hypogonadism appears to be mediated by deficiency of both testosterone and $\mathrm{E}_{2}$, although $\mathrm{E}_{2}$ deficiency appears to be most important. testosterone effects may be partly indirect, through anabolic effects on muscle mass, which increases bone mass by increasing mechanical load. Untreated men and women with congenital aromatase deficiency develop eunuchoid skeletal proportions, continued linear growth and high-turnover osteoporosis (Morishima et al. 1995, Carani et al. 1997, 
Herrmann et al. 2002). A similar skeletal phenotype was described in a man with a homozygous ER $\alpha$ mutation (Smith et al. 1994). In the cases of aromatase deficiency, but not in the case of ER $\alpha$ deficiency, estrogen treatment reduced bone turnover, fused epiphyses and improved bone density. In a cross-sectional study, women with complete androgen insensitivity syndrome (XY karyotype) had moderate deficits in lumbar spine BMD that was more marked in those with poor adherence to estrogen therapy (Marcus et al. 2000). There was no deficit in areal BMD in women with partial androgen insensitivity suggesting some beneficial effects on BMD of residual androgen responsiveness in bone or muscle. While instructive, the phenotype of patients with deficiency of sex steroid action during fetal, childhood and pubertal growth and development may not accurately represent the pathophysiology of bone disease that occurs during adult onset hypogonadism (Khosla et al. 2001, Finkelstein et al. 2016).

Cross-sectional and longitudinal observational studies of associations between areal BMD and sex steroid levels in older men have shown stronger associations with $\mathrm{E}_{2}$ than with $\mathrm{T}$, although associations are generally weak (Khosla et al. 2001). The association between serum sex steroid levels and bone microarchitectural parameters was examined in 440 elderly Swedish men (Vandenput et al. 2014). Serum $E_{2}$, measured by mass spectrometry, was inversely associated with cortical porosity. The importance of $\mathrm{E}_{2}$ action on bone is supported by a genome-wide association study showing a common $\mathrm{ER} \alpha$ polymorphism is associated with reduced cortical volumetric BMD (Paternoster et al. 2013), and also by interventional studies.

Nine weeks of AI treatment in 15 healthy older men increased $\mathrm{T}$, modestly reduced $\mathrm{E}_{2}$ and reversibly increased bone remodelling as measured by serum C-terminal telopeptide of type 1 collagen (CTX) (Taxel et al. 2001). In a 12-month RCT of AI treatment in 69 older men with low testosterone levels, spine BMD slightly but significantly declined in the AI group without significant changes in bone remodelling markers (Burnett-Bowie et al. 2009). The AI raised testosterone levels into the eugonadal range for young men but, as with other studies of AI in men without gonadotropin suppression, $\mathrm{E}_{2}$ only modestly declined and remained within the normal range (Burnett-Bowie et al. 2009). In a 6-week study of 59 healthy elderly men, LHRHa were combined with AI plus topical testosterone add-back, topical $\mathrm{E}_{2}$ add-back, both or neither (FalahatiNini et al. 2000). Bone remodelling as measured by urinary total deoxypyridinoline and $\mathrm{N}$-terminal of type 1 collagen increased in groups without $\mathrm{E}_{2}$ add-back, but there was no statistically independent effect of testosterone. Serum $\mathrm{N}$-terminal propeptide of type 1 collagen (P1NP) fell in groups without $\mathrm{E}_{2}$ add-back, with no independent effect of testosterone, suggesting an $\mathrm{E}_{2}$-dependent reduction in collagen synthesis by all cells of osteoblast lineage (Khosla et al. 2001). Osteocalcin similarly fell in groups with no testosterone or $\mathrm{E}_{2}$ add-back, suggested to reflect apoptosis of mature osteoblasts, but this was prevented by either testosterone or $\mathrm{E}_{2}$ add-back, or both. Shortterm studies of bone remodelling markers do not allow conclusions to be made regarding net bone resorption or bone formation (Seeman \& Martin 2015).

Finkelstein and coworkers applied their experimental paradigm to biochemical markers of bone turnover and BMD to isolate the individual effects of testosterone and $\mathrm{E}_{2}$ deficiency on the high-turnover bone loss that occurs in hypogonadism (Finkelstein et al. 2016). Serum CTX and P1NP were measured. Areal BMD was measured using DXA and spine trabecular BMD by quantitative computed tomography. Elevations in bone turnover markers, measured as a percentage of baseline, tended to be higher in men who received AI compared to those that did not, but in this short-term study, these changes were only significant for CTX. Within both cohorts, CTX elevations were also higher in those who received lower doses of testosterone replacement. Although changes in BMD were small over 16 weeks, similar patterns were seen with respect to BMD, with greater declines in men receiving AI than men who did not, and greater declines in men with lower testosterone replacement doses in both AI and no AI cohorts. Trabecular BMD at the spine declined by $4-5 \%$ in men receiving AI, and was significantly different than control at each testosterone replacement dose. A subset of men receiving AI also underwent high-resolution peripheral quantitative CT to measure bone microarchitecture at the distal radius and tibia. Volumetric BMD tended to decline from baseline in men receiving AI. Volumetric BMD and changes in indices of skeletal microarchitecture were independent of testosterone replacement dose, suggesting a predominant effect of $\mathrm{E}_{2}$ deficiency.

In the context of ADT for PCa, few studies have looked specifically at the efficacy of estrogens in preventing bone deterioration. In a nested BMD substudy of the PATCH trial, 74 men with locally advanced or metastatic PCa, randomized to ADT with LHRHa or $\mathrm{E}_{2}$ patches, underwent DXA scans at baseline, 1 year and 2 years (Langley et al. 2016). Data were available on 60 men for the primary outcome of 1-year change in lumbar spine BMD. At all

Published by Bioscientifica Ltd 
anatomical sites, at both time points, BMD increased compared with baseline in the $\mathrm{E}_{2}$ arm and decreased in the LHRHa arm. This resulted in a $6.7 \%(3.7-9.7 \% ; P<0.001)$ improved $\mathrm{BMD}$ at the lumbar spine in the $\mathrm{E}_{2}$ group compared with LHRHa group (mean absolute change of $+0.069 \mathrm{~g} / \mathrm{cm}^{3}$ vs $-0.021 \mathrm{~g} / \mathrm{cm}^{3}$, respectively). Fractures were not reported, but the PATCH bone substudy provides strong evidence that ADT using transdermal $\mathrm{E}_{2}$ prevents the decline in BMD caused by LHRHa.

Skeletal events including fractures were measured as a secondary outcome in the SPCG-5 trial of intramuscular PEP compared with CAB (Hedlund et al. 2008). After median follow-up of 11.7 years (10.1-13.7), 18 skeletal events including 9 femoral neck fractures and 7 spinal cord compressions had occurred in the CAB group $(n=455)$ and 0 had occurred in the PEP group $(n=455)(P=0.001)$. Bone density was not reported in the SPCG-5 trial.

\section{Effect of estradiol on body composition and insulin resistance}

Adverse changes in body composition are important drivers of insulin resistance leading to diabetes and elevations in cardiovascular risk. Both T-deficiencyinduced muscle loss and $\mathrm{E}_{2}$-deficiency-induced visceral fat gain may be important in this process. Muscle loss is likely to be important via dual mechanisms of loss of tissue capable of insulin-independent glucose uptake; and also loss of myokine signalling (Basaria \& Bhasin 2012).

Androgens, acting on the AR, promote myogenic differentiation of mesodermal stem cells and inhibit adipogenic differentiation (Bhasin et al. 2003). Loss of these AR-mediated effects in men undergoing LHRHa therapy would not be expected to be mitigated by estrogens. However, some fat mass-reducing effects of androgens may be mediated by aromatization to estrogens. Global aromatase knockout mice have more fat mass and less muscle mass than wild type mice, and men and postmenopausal women have a different body fat distribution pattern than premenopausal women (Jones et al. 2000). Case reports of men with congenital aromatase deficiency describe excess adiposity and insulin resistance (Jones et al. 2007) and AI treatment in healthy men reduces insulin sensitivity (Gibb et al. 2016). Similarly, mice (Bryzgalova et al. 2006) and men (Smith et al. 1994) with defective ER $\alpha$ have insulin resistance.

While most evidence suggests that skeletal muscle is an androgen-dependent organ, a population-based crosssectional study of 3014 elderly Swedish men, serum $\mathrm{E}_{2}$ but not testosterone was positively associated with lean mass (Vandenput et al. 2010). Conflicting results with respect to muscle strength were obtained in a Dutch cross-sectional study (van den Beld et al. 2000). By comparison, Finkelstein reported that $\mathrm{E}_{2}$ did not exert an effect independent of testosterone on total body lean mass, thigh muscle area or leg press strength. However, increases in percentage body fat, intra-abdominal fat area and subcutaneous fat area were primarily related to changes in $\mathrm{E}_{2}$ levels (Finkelstein et al. 2013).

In obese young men with low-normal or frankly low free $\mathrm{T}$, a 14-week placebo-controlled RCT of an LHRH antagonist with exogenous testosterone gel $10 \mathrm{~g} /$ day combined with dutasteride (to inhibit testosterone conversion to the more potent AR agonist dihydrotestosterone, DHT), AI or placebo pill was performed to isolate the body composition effects of testosterone that were DHT- or $\mathrm{E}_{2}$-dependent (Juang et al. 2014). A separate triple-placebo (injection/gel/pill) group acted as controls. Mean total testosterone concentration increased from group means of $9.5-13.1 \mathrm{nmol} / \mathrm{L}$ to means of 12.2 (triple placebo), 25.3 (AI pill), 38.4 (dutasteride pill) and $41.4 \mathrm{nmol} / \mathrm{L}$ (placebo pill). Post-treatment $\mathrm{E}_{2}$ in these groups was 76.3 (triple placebo), 11.7 (AI pill), 156.5 (dutasteride pill), $203.3 \mathrm{pmol} / \mathrm{L}$ (placebo pill), as measured by immunoassay. Body composition improved (increased fat free mass percentage and decreased fat mass) with testosterone treatment of these men when it was combined with placebo or dutasteride pills but not when it was combined with AI, suggesting that these changes were $\mathrm{E}_{2}$-dependent. Insulin sensitivity (IS), measured using euglycaemic hyperinsulinemic glucose clamp, significantly improved only in the dutasteride group, suggesting that DHT attenuates potential benefits of testosterone and $\mathrm{E}_{2}$ on IS. However, this small $(n=57)$, short-term study requires confirmation.

\section{Effect of estradiol on neurocognitive symptoms}

Both $\mathrm{E}_{2}$ and androgens have genomic and non-genomic effects in the brain that may influence cognition in men (Nelson et al. 2008). It is unknown whether subtle cognitive effects associated with testosterone deficiency, for example, on working memory, would be mitigated by $\mathrm{E}_{2}$. There is some suggestion that certain castration effects might be due to $E_{2}$ withdrawal, such as effects on rate of learning (Nelson et al. 2008). A small 12-week RCT of testosterone supplementation with or without anastrozole in healthy eugonadal elderly men observed improvements in spatial memory in both groups compared with men receiving double placebo (Cherrier et al. 2005). Men in

Published by Bioscientifica Ltd. 
the T-only group, but not men in the testosterone plus anastrozole group, had improvements in verbal memory, suggesting possible estradiol dependence of this effect (with the caveat regarding poor central nervous system penetration of anastrozole, discussed above). However, the cognitive component of the much larger testosterone trials showed that 12 months of testosterone treatment in older men with mildly low testosterone and ageassociated memory impairment did not improve cognition (Resnick et al. 2017).

In the ADT context, a non-randomized pilot study investigated the effect of high-dose parenteral $\mathrm{E}_{2}$ as secondline ADT in 18 men with CRPC (Beer et al. 2006). Cognitive assessments were conducted at baseline prior to switching to $\mathrm{E}_{2}$, and 4 weeks later. A cohort of men with castratesensitive PCa continuing conventional ADT, and another cohort of healthy men, acted as controls. On individual repeated measures analysis verbal memory performance improved with $\mathrm{E}_{2}$ therapy and did not change in the control groups, but the interaction of group and visit was statistically insignificant in overall analysis of variance. A 9-week pilot RCT of low-dose oral $\mathrm{E}_{2}$ in 27 men receiving LHRHa demonstrated no improvements in cognitive function compared with placebo (Taxel et al. 2004). A 24-week RCT in 25 men receiving CAB administered neuropsychological tests prior to therapy, after 12 weeks of $\mathrm{CAB}$ and after a subsequent 12 weeks of $\mathrm{CAB}$ plus lowdose oral $\mathrm{E}_{2}$ or placebo (Matousek \& Sherwin 2010). The hypothesized decrement in visual and spatial test scores after 12 weeks of $C A B$ was not observed, and there was no further improvement in scores with $\mathrm{E}_{2}$ add-back.

\section{Estradiol is unlikely to mitigate effects of ADT that are direct sequelae of testosterone deficiency}

Parts of the hypogonadal syndrome that are directly mediated by loss of AR signalling would not be expected to improve with $\mathrm{E}_{2}$ administration (Table 1). A decrement in haemoglobin is expected with ADT, often leading to a mild normocytic and normochromic anaemia. This is clearly an androgen-dependent effect. The mechanisms may involve reduced activation of $\mathrm{AR}$ on erythroid progenitors, unsuppression of hepcidin leading to reduced iron availability for erythropoiesis, and possibly reduced erythropoietin secretion, although data are contradictory (Grossmann \& Zajac 2012).

As discussed above, relationships of sex hormones to muscle size and function remain to be fully elucidated. While observational data have shown variable associations of sex hormones with lean mass in healthy elderly men (van den Beld etal.2000, Vandenput etal.2010), Finkelstein's experiments on healthy young men suggest that shortterm changes in lean mass, muscle size and strength are androgen-dependent (Finkelstein et al. 2013). Decrements over 16 weeks became evident with testosterone add-back doses of $1.25 \mathrm{~g}$ or less corresponding to mean testosterone concentrations of $200 \mathrm{ng} / \mathrm{dL}(6.9 \mathrm{nmol} / \mathrm{L})$ or less.

\section{Effects of estradiol on prostate cancer}

The VACURG studies found that DES in a dose of $1 \mathrm{mg}$ daily, which did not reliably produce castrate testosterone levels, was no less effective on PCa than the $5 \mathrm{mg}$ dose which did (Byar \& Corle 1988). This finding raised the possibility that estrogens might have additional oncologic benefits. DES was shown to have direct cytotoxic effects on PCa cells in concentrations achieved in vivo by very high-dose infusions, historically used with palliative benefit in patients, although this may have been a nonER-mediated pharmacological effect (Schulz et al. 1988, 1990, Robertson et al. 1996, Geier et al. 2010).

Subsequent epidemiologic, basic and clinical studies have demonstrated the role of estrogens in PCa to be highly complex (Di Zazzo et al. 2016, Rahman et al. 2016). The ageassociated rise in PCa incidence coincides with a decrease in circulating free testosterone/ $\mathrm{E}_{2}$ ratio due to declines in hypothalamic-pituitary-testicular axis function and increases in sex hormone binding globulin (SHBG) (Rahman et al. 2016, Cooke et al. 2017). However, more defined associations between $\mathrm{E}_{2}$ concentrations or testosterone $/ \mathrm{E}_{2}$ ratios and PCa incidence have not been established.

Normal and neoplastic prostate tissue expresses ER $\alpha$, ER $\beta$ and GPER. ER $\alpha$ is predominantly localized in normal and tumour stroma; ER $\beta$ is highly expressed in normal prostate epithelium and stroma but is downregulated during PCa development (Leach et al. 2016). ER $\alpha$ signalling promotes cell cycle progression, inflammation and carcinogenesis in the prostate, while ER $\beta$ signalling is anti-proliferative, pro-apoptotic and protective, although this may depend on the ER $\beta$ isoform (Risbridger et al. 2010, Leach et al. 2016). GPER-specific activation appears to inhibit PCa growth (Chan et al. 2010, Lau \& To 2016). Prostate stromal cells contain aromatase and synthesize $\mathrm{E}_{2}$ locally from available androgens (Risbridger et al. 2007). $\mathrm{E}_{2}$ acts on local stromal and epithelial cells and there is paracrine regulation of its production, but this is lost in PCa. Increased aromatase expression in metastatic PCa lesions has been demonstrated (Miftakhova et al. 2016). Estrogens along with other non-androgen ligands may be able to activate mutated ARs as one mechanism of

Published by Bioscientifica Ltd 
castrate resistance (Leach et al. 2016). However, clinically, AIs have been an unsuccessful strategy to treat CRPC (Smith et al. 2002b).

The net effect of estrogens or the androgen/estrogen ratio on $\mathrm{PCa}$ development and progression has not been established, and is unlikely to be simply defined (reviewed in Rahman et al. 2016 and Di Zazzo et al. 2016). Overall experience with the therapeutic use of estrogens in PCa does not suggest a clinically important pro-carcinogenic effect. A systematic review of 20 RCTs of the use of high-dose parenteral $\mathrm{E}_{2}$ as ADT for locally advanced or metastatic PCa found no evidence that $\mathrm{E}_{2}$ treatment differed in efficacy from LHRHa or orchiectomy when comparing overall mortality (Norman et al. 2008). Oncologic outcomes from the PATCH study are yet to be reported (Langley et al. 2013).

LHRHa produce sustained suppression of LH and testosterone levels, but FSH levels tend to recover during long-term treatment (Santen et al. 1984, Bhasin et al. 1994). This FSH 'escape' is not seen with LHRH antagonists (Klotz et al. 2008) and appears also not to occur with ADT using high-dose estrogen therapy (Ockrim et al. 2003). Orchiectomy results in high FSH and LH levels due to the removal of negative feedback. FSH receptors are expressed in PCa and other tumour tissues and FSH binding may have a pro-angiogenic effect (Radu et al. 2010). There has been considerable interest in the potential clinical relevance of FSH escape during ADT (Crawford et al. 2017); however, any oncological advantage of maintaining FSH suppression during ADT, including with estrogens, is yet to be proven.

\section{Potential adverse effects of estrogen therapy}

\section{Venous thromboembolism and cardiovascular risk}

Cardiovascular toxicity from oral DES comprised fluid retention, hypertension, and arterial and venous thromboembolism, manifesting as stroke, myocardial infarction, deep vein thrombosis and pulmonary embolism (Byar 1973, de Voogt et al. 1986). Orally administered estrogens induce liver synthesis of coagulation factors, renin substrate, and many carrier proteins including SHBG (Geola et al. 1980, Schoultz et al. 1989). There are also alterations in lipoprotein metabolism with increases in triglycerides and HDL cholesterol with reduced hepatic cholesterol uptake from HDL (Schoultz et al. 1989). The adverse cardiovascular impact of early DES regimens for PCa is likely to have been predominantly due to the prothrombotic milieu created. Orally administered estrogens for PCa increase procoagulant factors such as Factor VII, and decrease antithrombin III, on a background of an existing hypercoagulable state (Henriksson et al. 1986, 1989). This effect is amplified for synthetic orally administered estrogens because unlike $\mathrm{E}_{2}$, they are not converted to the less-potent estrone by gut-wall 17-beta hydroxysteroid dehydrogenase (Schoultz et al. 1989).

Transdermal administration of $\mathrm{E}_{2}$ avoids hepatic first pass metabolism so that up to 20 -fold lower doses can be administered to achieve similar serum levels (Powers et al. 1985). This means that hepatocytes are exposed to lower doses and alterations in protein synthesis and accumulation of estrone sulphate are greatly reduced (Damber et al. 1979, Powers et al. 1985, Henriksson et al. 1990). Even high doses of parenteral $\mathrm{E}_{2}$ used for ADT in men with PCa largely avoid disturbance in hepatic protein metabolism (Stege et al. 1987, Henriksson et al. 1990, Ockrim et al. 2005).

Several beneficial physiological effects of estrogen on vascular function, atherosclerosis, lipoprotein metabolism and cardiomyocyte protection are proposed (Morselli et al. 2017). In an uncontrolled study of oral $\mathrm{E}_{2}$ $(0.5,1$ or $2 \mathrm{mg}$ daily) for 9 weeks in 22 healthy elderly men, lipid parameters improved from baseline (Giri et al. 1998). In an 8-week double-blind RCT enrolling 12 men receiving non-estrogen $\mathrm{ADT}$, the effect of oral $\mathrm{E}_{2} 1 \mathrm{mg}$ daily on vascular responsiveness was compared to placebo (Komesaroff et al. 2001). $\mathrm{E}_{2}$ - but not placebo-treated men showed reduced vasoconstrictor responses to angiotensin II and norephinephrine, enhanced endothelial basal nitric oxide release, and reductions in systolic and diastolic blood pressure. Additionally, there are a range of proposed cellular mechanisms by which estrogens may be important for cardiomyocyte protection in the context of ageing, insulin resistance, hypertension and ischaemia (Morselli et al. 2017).

\section{Gynaecomastia}

Gynaecomastia reflects the ratio of AR and ER signalling in breast tissue. Reported rates following medical or surgical castration are 1-16\% (Sharifi et al. 2005) but gynaecomastia is more frequent when antiandrogen monotherapy or estrogens are used. In PATCH, when it was systematically evaluated, $75 \%$ of men receiving $\mathrm{E}_{2}$ experienced gynaecomastia compared with $19 \%$ receiving LHRHa (Langley et al. 2013). For symptomatic breast enlargement requiring intervention, the proportions were $9 \%$ and $0 \%$, respectively.

Published by Bioscientifica Ltd 
Pre-treatment breast irradiation, given as a single dose, has efficacy in preventing gynaecomastia and was part of older protocols for oral DES (Beck et al. 1978) and intramuscular PEP (Norman et al. 2008). In SPCG-5, $240 \mathrm{mg}$ intramuscular PEP per month over 11 years caused gynaecomastia in the majority of patients: $60 \%$ of those who received prophylactic breast irradiation and $84 \%$ of those who did not (by comparison, 48\% of irradiated and 36\% non-irradiated patients in the CAB group) (Hedlund et al. 2008). Severe gynaecomastia, defined as breast enlargement to a size bigger than the patient's fist, occurred in $2 \%$ of PEP patients who received irradiation and $4 \%$ of those who did not. Three patients in the PEP group and no patients in the CAB group ceased treatment because of gynaecomastia.

\section{Low-dose parenteral estradiol add-back: the best solution?}

The concept of $\mathrm{E}_{2}$ add-back in men receiving LHRHa refers to the administration of $\mathrm{E}_{2}$ in doses designed to return circulating levels to normal while castrate testosterone levels are maintained. The aim of such a strategy is to reduce the incidence of ADT side effects that are due to $\mathrm{E}_{2}$ deficiency, without reducing treatment efficacy and without introducing estrogenic-side effects. However, such a strategy has not been comprehensively studied, there are no approved formulations of low-dose estrogens for men, and the dosing required to achieve physiological rather than pharmaceutical effects is uncertain.

An $E_{2}$ add-back strategy would ideally avoid the use of oral and synthetic estrogens to lower risks of cardiovascular or thromboembolic adverse effects. First pass hepatic metabolism of orally administered $\mathrm{E}_{2}$ also results in higher levels of circulating estrone than $\mathrm{E}_{2}$ (Townsend et al. 1981). Transdermal $E_{2}$ application results in absorption with minimal metabolism meaning that lower doses can be used, and there is a higher, more physiological, ratio of the serum $\mathrm{E}_{2}$ to estrone, and less accumulation of conjugated forms (Powers et al. 1985). This may be important in reducing the risk of gynaecomastia.

\section{Estradiol reference ranges and thresholds for effect}

There is some data from population-based cohorts to establish an approximate reference range for $\mathrm{E}_{2}$ in healthy elderly men. In the Health in Men Study cohort from Australia, 3690 community dwelling elderly men aged $77.0 \pm 3.6$ years had morning sex steroids measured by mass spectrometry (Yeap et al. 2012). This cohort excluded men with a history of androgen or antiandrogen therapy, orchiectomy or PCa. BMI was $26.5 \pm 3.6 \mathrm{~kg} / \mathrm{m}^{2}$ and $47.1 \%$ self-assessed their own health to be very good or excellent. The mean $\mathrm{E}_{2}$ concentration was $73.4 \mathrm{pmol} / \mathrm{L}$ with a reference range (2.5th-97.5th percentile) of 25.0$139.9 \mathrm{pmol} / \mathrm{L}$. These ranges are consistent with $\mathrm{E}_{2}$ levels in 1830 elderly Swedish men taking part in the MrOS study (Vandenput et al. 2010). However, more studies are needed to more definitively establish age-adjusted reference ranges for $\mathrm{E}_{2}$, in particular among older men in whom hypogonadism has been rigorously excluded.

There are limited data on the level of serum $\mathrm{E}_{2}$ that might protect against the $\mathrm{E}_{2}$-dependent manifestations of hypogonadism in the context of castrate levels of $\mathrm{T}$. In comparing blood levels of $\mathrm{E}_{2}$ and testosterone with biologic effects, it is important to recognize that $E_{2}$ is produced locally from aromatase in target tissues and acts in a paracrine fashion (Simpson 2003). In healthy men and in studies of medically castrated men undergoing graded testosterone add-back, serum levels of $\mathrm{E}_{2}$ reflect the total $\mathrm{E}_{2}$ that has diffused into the blood from all tissues having been synthesized by aromatase and escaped local tissue metabolism. These blood levels, no matter how accurately measured, are an indirect reflection of total estrogen signalling which is further locally modulated by sulphoconjugation and deconjugation of estrogens (Song 2001).

As discussed, the studies of Finkelstein do not contain a cohort of men with graded $\mathrm{E}_{2}$ replacement in the absence of testosterone replacement (Finkelstein et al. 2013, 2016, Taylor et al. 2016). However, accepting that at physiologic levels testosterone is unimportant for vasomotor stability, $\mathrm{E}_{2}$ levels greater than $25 \mathrm{pg} / \mathrm{mL}(92 \mathrm{pmol} / \mathrm{L})$ achieved by graded testosterone add-back were sufficient to return VMS to control levels (Taylor et al. 2016). For bone, threshold levels of $200 \mathrm{ng} / \mathrm{dL}(6.9 \mathrm{nmol} / \mathrm{L})$ for testosterone and $10 \mathrm{pg} / \mathrm{mL}(37 \mathrm{pmol} / \mathrm{L})$ for $\mathrm{E}_{2}$ were demonstrated, below which the risk of bone loss began to increase (Finkelstein et al. 2016) (Table 1). In the PATCH bone substudy (Langley et al. 2016), despite a 7\% better lumbar spine BMD in the $\mathrm{E}_{2}$ arm compared with LHRHa arm at 12 months, there was no association between serum $\mathrm{E}_{2}$ level and BMD change at any anatomical site within the $\mathrm{E}_{2}$ arm. This could be because numbers were small, or because the achieved $\mathrm{E}_{2}$ levels were well above a threshold above which no further benefit can be obtained.

The extent to which $\mathrm{E}_{2}$ replacement in men undergoing ADT might ameliorate body composition 
effects is unknown. Lean mass, muscle mass and strength appear to be related to androgen action directly. In Finkelstein's study, body fat accumulation appeared to be a predominantly estrogenic effect (Finkelstein et al. 2013). Men receiving AI gained body fat regardless of testosterone replacement dose. In men not receiving AI, a testosterone replacement dose of $5 \mathrm{~g} /$ day was sufficient to prevent fat gain, whereas men receiving $2.5 \mathrm{~g} /$ day did gain fat mass. Mean testosterone and $\mathrm{E}_{2}$ levels in the $5 \mathrm{~g}$ /day group were $470 \pm 201 \mathrm{ng} / \mathrm{dL}(16.3 \pm 7.0 \mathrm{nmol} / \mathrm{L})$ and $18.2 \pm 10.2 \mathrm{pg} /$ $\mathrm{mL}(67 \pm 37 \mathrm{pmol} / \mathrm{L})$, respectively. Mean testosterone and $\mathrm{E}_{2}$ levels in the $2.5 \mathrm{~g} /$ day group were $337 \pm 173 \mathrm{ng} / \mathrm{dL}$ $(11.9 \pm 6.0 \mathrm{nmol} / \mathrm{L})$ and $11.9 \pm 5.7 \mathrm{pg} / \mathrm{mL}(44 \pm 21 \mathrm{pmol} / \mathrm{L})$. An inference is that an $\mathrm{E}_{2}$ level between 44 and $67 \mathrm{pmol} / \mathrm{L}$ would prevent fat gain (Table 1). But whether that applies to men with castrate testosterone levels is unknown.

Both $\mathrm{E}_{2}$ and testosterone appear to be important for sexual function. In Finkelstein's study, when testosterone levels were in the mild-moderately hypogonadal range (200-400 ng/dL; $6.9-13.9 \mathrm{nmol} / \mathrm{L})$, greater decrements in sexual desire were seen when $\mathrm{E}_{2}$ levels were $<10 \mathrm{pg} / \mathrm{mL}$ $(<37 \mathrm{pmol} / \mathrm{L})$ compared to when $\mathrm{E}_{2}$ levels were $>10 \mathrm{pg} /$ $\mathrm{mL}(>37 \mathrm{pmol} / \mathrm{L})$ (Finkelstein et al. 2013). The effects of $\mathrm{E}_{2}$ above and below $37 \mathrm{pmol} / \mathrm{L}$ in the context of castrate testosterone levels are unknown.

\section{Estradiol dosing to achieve physiologic levels in the context of non-estrogen ADT}

There is very little data to inform dosing estimates for new studies investigating parenteral $\mathrm{E}_{2}$ add-back in men undergoing non-estrogen ADT. Earlier studies of high-dose estrogen therapy do not provide useful information because the aim of this therapy was to achieve medical castration, not to achieve physiologic $\mathrm{E}_{2}$ levels, and $\mathrm{E}_{2}$ levels were generally not reported. When parenteral $E_{2}$ is used to achieve medical castration, a dose of at least $240 \mathrm{mg}$ of $\mathrm{E}_{2}$ per month is required (Norman et al. 2008).

In a pilot RCT of $\mathrm{E}_{2}$ add-back in men receiving LHRHa, men were given 9 weeks of therapy with oral $\mathrm{E}_{2}(1 \mathrm{mg} /$ day) or placebo (Taxel et al. 2002). At baseline men had low but detectable $\mathrm{E}_{2}$ associated with castrate testosterone levels, measured by immunoassay. Oral $\mathrm{E}_{2}$ recapitulated normal to high $\mathrm{E}_{2}$ levels based on the reference intervals of the assay, and reduced biochemical markers of bone turnover at 9 weeks. Breast tenderness was more frequently reported in the $\mathrm{E}_{2}$ arm. However, immunoassay is known to inaccurately measure low $\mathrm{E}_{2}$ concentrations in men (Handelsman et al. 2014).
Other studies have added estrogens to ADT, without aiming for physiological replacement. DES $1 \mathrm{mg}$ /day was added to the regimen of 14 men established on nonestrogen ADT for non-metastatic PCa (Scherr et al. 2002). Urinary collagen type I cross-linked N-telopeptides were measured and corrected for creatinine as a marker of bone turnover. Compared to a comparison group receiving $1 \mathrm{mg}$ DES monotherapy, urinary N-telopeptide/creatinine was significantly higher in the ADT group. This difference was abolished by the addition of $1 \mathrm{mg}$ DES to that group. However, initial allocation was non-randomized, and there was no control group of men continuing ADT without DES, and the time frame for sampling in relation to medication changes is incompletely described.

In another pilot study, 12 men with bothersome hot flushes due to LHRHa were treated with $\mathrm{E}_{2} 50$ or $100 \mu \mathrm{g} / 24 \mathrm{~h}$ patches changed twice weekly (Gerber et al. 2000). Only those receiving the higher dose had a significant increase in $\mathrm{E}_{2}$ level from baseline. Mean $\mathrm{E}_{2}$ in this group was $26.9 \mathrm{pg} / \mathrm{mL}$ (98.8 pmol/L) compared with $12.1 \mathrm{pg} / \mathrm{mL}$ $(44 \mathrm{pmol} / \mathrm{L})$ at baseline, measured by immunoassay. The frequency and severity of hot flashes were reduced with this dose.

\section{Side effects of low-dose parenteral estradiol add-back}

Whether low-dose parenteral $\mathrm{E}_{2}$ add-back in men receiving LHRHa would add to side effects is unknown. Hypothesized benefits of this strategy include reduction in hot flushes, amelioration of bone density and microstructural deterioration and body fat accumulation (Table 1). It is unlikely, given the safety of high-dose parenteral $\mathrm{E}_{2}$ for $\mathrm{ADT}$, that low-dose $\mathrm{E}_{2}$ would increase cardiovascular or thromboembolic risk, or have clinically significant pro-carcinogenic effects. Gynaecomastia would theoretically be promoted by further increasing the ER/AR signalling ratio at the breast, but whether there would be a clinically significant increase above the rate and severity associated with LHRHa alone remains to be established.

\section{Conclusion}

Given the clinical benefits of LHRHa are mediated by testosterone deficiency, and many of the important adverse effects are mediated by $\mathrm{E}_{2}$ deficiency, there is a hypothesis of benefit for trials of parenteral $\mathrm{E}_{2}$ replacement in men receiving LHRHa. This is a unique clinical and ethical paradigm in which the biologic effects of $\mathrm{E}_{2}$ in men in the absence of testosterone may be directly observed.

Published by Bioscientifica Ltd. 


\section{Declaration of interest}

The authors declare that there are no conflict of interest that could be perceived as prejudicing the impartiality of this review.

\section{Funding}

N R is supported by an Australian Postgraduate Award. A C is supported by an Endocrine Society of Australia Postdoctoral Award. M G received support from the National Health and Medical Research Council of Australia (NHMRC projects APP1099173, APP1062073, APP1030123).

\section{Author contribution statement}

N R wrote the initial draft which was then revised by A C and M G.

\section{References}

Albertsen PC, Moore DF, Shih W, Lin Y, Li H \& Lu-Yao GL 2011 Impact of comorbidity on survival among men with localized prostate cancer. Journal of Clinical Oncology 29 1335-1341. (doi:10.1200/ JCO.2010.31.2330)

Atala A, Amin M \& Harty JI 1992 Diethylstilbestrol in treatment of postorchiectomy vasomotor symptoms and its relationship with serum follicle-stimulating hormone, luteinizing hormone, and testosterone. Urology 39 108-110. (doi:10.1016/00904295(92)90264-W)

Basaria S \& Bhasin S 2012 Targeting the skeletal muscle-metabolism axis in prostate-cancer therapy. New England Journal of Medicine $\mathbf{3 6 7}$ 965-967. (doi:10.1056/NEJMcibr1203160)

Beck PH, McAnich JW, Goebel JL \& Stutzman RE 1978 Plasma testosterone in patients receiving diethylstilbestrol. Urology 11 157-160. (doi:10.1016/0090-4295(78)90096-1)

Beer TM, Bland LB, Bussiere JR, Neiss MB, Wersinger EM, Garzotto M, Ryan CW \& Janowsky JS 2006 Testosterone loss and estradiol administration modify memory in men. Journal of Urology $\mathbf{1 7 5}$ 130-135. (doi:10.1016/S0022-5347(05)00049-2)

Beer TM, Armstrong AJ, Rathkopf DE, Loriot Y, Sternberg CN, Higano CS, Iversen P, Bhattacharya S, Carles J, Chowdhury S, et al. 2014 Enzalutamide in metastatic prostate cancer before chemotherapy. New England Journal of Medicine 371 424-433. (doi:10.1056/ NEJMoa1405095)

Bhasin S, Berman N \& Swerdloff RS 1994 Follicle-stimulating hormone (FSH) escape during chronic gonadotropin-releasing hormone $(\mathrm{GnRH})$ agonist and testosterone treatment. Journal of Andrology $\mathbf{1 5}$ 386-391. (doi:10.1002/j.1939-4640.1994.tb00470.x)

Bhasin S, Taylor WE, Singh R, Artaza J, Sinha-Hikim I, Jasuja R, Choi H \& Gonzalez-Cadavid NF 2003 The mechanisms of androgen effects on body composition: mesenchymal pluripotent cell as the target of androgen action. Journals of Gerontology: Series A, Biological Sciences and Medical Sciences 58 M1103-M1110. (doi:10.1093/gerona/58.12. M1103)

Biegon A, Kim SW, Alexoff DL, Jayne M, Carter P, Hubbard B, King P, Logan J, Muench L, Pareto D, et al. 2010 Unique distribution of aromatase in the human brain: in vivo studies with PET and [N-methyl-11C]vorozole. Synapse 64 801-807. (doi:10.1002/ syn.20791)

Björnström L \& Sjöberg M 2005 Mechanisms of estrogen receptor signaling: convergence of genomic and nongenomic actions on target genes. Molecular Endocrinology 19 833-842. (doi:10.1210/ me.2004-0486)

Boström P, Wu J, Jedrychowski MP, Korde A, Ye L, Lo JC, Rasbach KA, Boström EA, Choi JH, Long JZ, et al. 2012 A PGC1- $\alpha$-dependent myokine that drives brown-fat-like development of white fat and thermogenesis. Nature 481 463-468. (doi:10.1038/nature10777)

Bourke L, Kirkbride P, Hooper R, Rosario AJ, Chico TJA \& Rosario DJ 2013 Endocrine therapy in prostate cancer: time for reappraisal of risks, benefits and cost-effectiveness? British Journal of Cancer 108 9-13. (doi:10.1038/bjc.2012.523)

Bryzgalova G, Gao H, Ahren B, Zierath JR, Galuska D, Steiler TL, Dahlman-Wright K, Nilsson S, Gustafsson JA, Efendic S, et al. 2006 Evidence that oestrogen receptor-alpha plays an important role in the regulation of glucose homeostasis in mice: insulin sensitivity in the liver. Diabetologia 49 588-597. (doi:10.1007/ s00125-005-0105-3)

Burnett-Bowie S-AM, McKay EA, Lee H \& Leder BZ 2009 Effects of aromatase inhibition on bone mineral density and bone turnover in older men with low testosterone levels. Journal of Clinical Endocrinology and Metabolism 94 4785-4792. (doi:10.1210/jc.2009-0739)

Byar DP 1973 The Veterans Administration Cooperative Urological Research Group's studies of cancer of the prostate. Cancer $\mathbf{3 2}$ 1126-1130. (doi:10.1002/1097-0142(197311)32:5<1126::AIDCNCR2820320518>3.0.CO;2-C)

Byar DP \& Corle DK 1988 Hormone therapy for prostate cancer: results of the Veterans Administration Cooperative Urological Research Group Studies. NCI Monographs 7 165-170.

Carani C, Qin K, Simoni M, Faustini-Fustini M, Serpente S, Boyd J, Korach KS \& Simpson ER 1997 Effect of testosterone and estradiol in a man with aromatase deficiency. New England Journal of Medicine 337 91-95. (doi:10.1056/NEJM199707103370204)

Chan QKY, Lam H-M, Ng C-F, Lee AYY, Chan ESY, Ng H-K, Ho S-M \& Lau K-M 2010 Activation of GPR30 inhibits the growth of prostate cancer cells through sustained activation of Erk1/2, c-jun/c-fos-dependent upregulation of p21, and induction of G(2) cell-cycle arrest. Cell Death and Differentiation 17 1511-1523. (doi:10.1038/cdd.2010.20)

Cherrier MM, Matsumoto AM, Amory JK, Ahmed S, Bremner W, Peskind ER, Raskind MA, Johnson M \& Craft S 2005 The role of aromatization in testosterone supplementation: effects on cognition in older men. Neurology 64 290-296. (doi:10.1212/01. WNL.0000149639.25136.CA)

Cheung AS, Zajac JD \& Grossmann M 2014 Muscle and bone effects of androgen deprivation therapy: current and emerging therapies. Endocrine-Related Cancer 21 R371-R394. (doi:10.1530/ERC-14-0172)

Cheung AS, de Rooy C, Hoermann R, Lim Joon D, Zajac JD \& Grossmann M 2016 Quality of life decrements in men with prostate cancer undergoing androgen deprivation therapy. Clinical Endocrinology 86 388-394. (doi:10.1111/cen.13249)

Cheung AS, Gray H, Schache AG, Hoermann R, Lim Joon D, Zajac JD, Pandy MG \& Grossmann M 2017 Androgen deprivation causes selective deficits in the biomechanical leg muscle function of men during walking: a prospective case-control study. Journal of Cachexia, Sarcopenia and Muscle 8 102-112. (doi:10.1002/jcsm.12133)

Collins L \& Basaria S 2012 Adverse effects of androgen deprivation therapy in men with prostate cancer: a focus on metabolic and cardiovascular complications. Asian Journal of Andrology 14 222-225. (doi:10.1038/aja.2011.109)

Cornford P, Bellmunt J, Bolla M, Briers E, De Santis M, Gross T, Henry AM, Joniau S, Lam TB, Mason MD, et al. 2017 EAU-ESTRIOSIOG Guidelines on Prostate Cancer. Part 2: Treatment of relapsing, metastatic, and castration-resistant prostate cancer. European Urology 71 630-642. (doi:10.1016/j.eururo.2016.08.002)

Cooke PS, Nanjappa MK, Ko C, Prins GS \& Hess RA 2017 Estrogens in male physiology. Physiological Reviews 97 995-1043. (doi:10.1152/ physrev.00018.2016)

Crawford ED, Schally AV, Pinthus JH, Block NL, Rick FG, Garnick MB, Eckel RH, Keane TE, Shore ND, Dahdal DN, et al. 2017 The potential role of follicle-stimulating hormone in the cardiovascular, metabolic, skeletal, and cognitive effects associated with androgen deprivation

Published by Bioscientifica Ltd. 
therapy. Urologic Oncology 35 183-191. (doi:10.1016/j. urolonc.2017.01.025)

Damber MG, Sandström B, Schoultz von B \& Stigbrand T 1979 A new and sensitive method for quantifying and comparing the biological potency of various estrogens in man. Acta Obstetricia et Gynecologica Scandinavica 58 527-530. (doi:10.3109/00016347909154612)

Davidson JM 1969 Effects of estrogen on the sexual behavior of male rats. Endocrinology 84 1365-1372. (doi:10.1210/endo-84-6-1365)

de Bono JS, Logothetis CJ, Molina A, Fizazi K, North S, Chu L, Chi KN, Jones RJ, Goodman OB, Saad F, et al. 2011 Abiraterone and increased survival in metastatic prostate cancer. New England Journal of Medicine 364 1995-2005. (doi:10.1056/NEJMoa1014618)

de Voogt HJ, Smith PH, Pavone-Macaluso M, de Pauw M \& Suciu S 1986 Cardiovascular side effects of diethylstilbestrol, cyproterone acetate, medroxyprogesterone acetate and estramustine phosphate used for the treatment of advanced prostate cancer: results from European Organization for Research on Treatment of Cancer Trials 30761 and 30762. Journal of Urology 135 303-307. (doi:10.1016/S00225347(17)45620-5)

Di Zazzo E, Galasso G, Giovannelli P, Di Donato M, Di Santi A, Cernera G, Rossi V, Abbondanza C, Moncharmont B, Sinisi AA, et al. 2016 Prostate cancer stem cells: the role of androgen and estrogen receptors. Oncotarget 7 193-208. (doi:10.18632/oncotarget.6220)

Diamond TH, Higano CS, Smith MR, Guise TA \& Singer FR 2004 Osteoporosis in men with prostate carcinoma receiving androgen-deprivation therapy: recommendations for diagnosis and therapies. Cancer 100 892-899. (doi:10.1002/cncr.20056)

Dinh KT, Reznor G, Muralidhar V, Mahal BA, Nezolosky MD, Choueiri TK, Hoffman KE, Hu JC, Sweeney CJ, Trinh Q-D, et al. 2016 Association of androgen deprivation therapy with depression in localized prostate cancer. Journal of Clinical Oncology 34 1905-1912. (doi:10.1200/JCO.2015.64.1969)

Donovan KA, Walker LM, Wassersug RJ, Thompson LMA \& Robinson JW 2015 Psychological effects of androgen-deprivation therapy on men with prostate cancer and their partners. Cancer $1214286-4299$. (doi:10.1002/cncr.29672)

Dorff TB, Flaig TW, Tangen CM, Hussain MHA, Swanson GP, Wood DP, Sakr WA, Dawson NA, Haas NB, Crawford ED, et al. 2011 Adjuvant androgen deprivation for high-risk prostate cancer after radical prostatectomy: SWOG S9921 study. Journal of Clinical Oncology 29 2040-2045. (doi:10.1200/JCO.2010.32.2776)

Falahati-Nini A, Riggs BL, Atkinson EJ, O'Fallon WM, Eastell R \& Khosla S 2000 Relative contributions of testosterone and estrogen in regulating bone resorption and formation in normal elderly men. Journal of Clinical Investigation 106 1553-1560. (doi:10.1172/JCI10942)

Finkelstein JS, Lee H, Burnett-Bowie S-AM, Pallais JC, Yu EW, Borges LF, Jones BF, Barry CV, Wulczyn KE, Thomas BJ, et al. 2013 Gonadal steroids and body composition, strength, and sexual function in men. New England Journal of Medicine 369 1011-1022. (doi:10.1056/ NEJMoa1206168)

Finkelstein JS, Lee H, Leder BZ, Burnett-Bowie S-AM, Goldstein DW, Hahn CW, Hirsch SC, Linker A, Perros N, Servais AB, et al. 2016 Gonadal steroid-dependent effects on bone turnover and bone mineral density in men. Journal of Clinical Investigation 126 1114-1125. (doi:10.1172/JCI84137)

Gadomska H, Barcz E, Cyganek A, Leocmach Y, Chadha-Boreham H \& Marianowski L 2002 Efficacy and tolerability of low-dose transdermal estrogen (Oesclim) in the treatment of menopausal symptoms. Current Medical Research and Opinion 18 97-102. (doi:10.1185/030079 902125000291)

Geier R, Adler S, Rashid G \& Klein A 2010 The synthetic estrogen diethylstilbestrol (DES) inhibits the telomerase activity and gene expression of prostate cancer cells. Prostate 70 1307-1312. (doi:10.1002/pros.21166)

Geola FL, Frumar AM, Tataryn IV, Lu KH, Hershman JM, Eggena P, Sambhi MP \& Judd HL 1980 Biological effects of various doses of conjugated equine estrogens in postmenopausal women. Journal of Clinical Endocrinology and Metabolism 51 620-625. (doi:10.1210/jcem51-3-620)

Gerber GS, Zagaja GP, Ray PS \& Rukstalis DB 2000 Transdermal estrogen in the treatment of hot flushes in men with prostate cancer. Urology 55 97-101. (doi:10.1016/s0090-4295(99)00370-2)

Gibb FW, Homer NZM, Faqehi AMM, Upreti R, Livingstone DE, McInnes KJ, Andrew R \& Walker BR 2016 Aromatase inhibition reduces insulin sensitivity in healthy men. Journal of Clinical Endocrinology and Metabolism 101 2040-2046. (doi:10.1210/jc.2015-4146)

Giri S, Thompson PD, Taxel P, Contois JH, Otvos J, Allen R, Ens G, Wu AHB \& Waters DD 1998 Oral estrogen improves serum lipids, homocysteine and fibrinolysis in elderly men. Atherosclerosis 137 359-366. (doi:10.1016/S0021-9150(98)00022-7)

Greenspan SL, Coates P, Sereika SM, Nelson JB, Trump DL \& Resnick NM 2005 Bone loss after initiation of androgen deprivation therapy in patients with prostate cancer. Journal of Clinical Endocrinology and Metabolism 90 6410-6417. (doi:10.1210/jc.2005-0183)

Grossmann M \& Zajac JD 2011 Management of side effects of androgen deprivation therapy. Endocrinology and Metabolism Clinics of North America 40 655-671. (doi:10.1016/j.ecl.2011.05.004)

Grossmann M \& Zajac JD 2012 Hematological changes during androgen deprivation therapy. Asian Journal of Andrology 14 187-192. (doi:10.1038/aja.2011.102)

Grossmann M, Cheung AS \& Zajac JD 2013 Androgens and prostate cancer; pathogenesis and deprivation therapy. Best Practice and Research Clinical Endocrinology and Metabolism 27 603-616. (doi:10.1016/j.beem.2013.05.001)

Guridi M, Tintignac LA, Lin S, Kupr B, Castets P \& Rüegg MA 2015 Activation of mTORC1 in skeletal muscle regulates whole-body metabolism through FGF21. Science Signaling 8 ra113-ra113. (doi:10.1126/scisignal.aab3715)

Hamilton EJ, Ghasem-Zadeh A, Gianatti E, Lim Joon D, Bolton D, Zebaze R, Seeman E, Zajac JD \& Grossmann M 2010 Structural decay of bone microarchitecture in men with prostate cancer treated with androgen deprivation therapy. Journal of Clinical Endocrinology and Metabolism 95 E456-E463. (doi:10.1210/jc.2010-0902)

Handelsman DJ, Newman JD, Jimenez M, McLachlan R, Sartorius G \& Jones GRD 2014 Performance of direct estradiol immunoassays with human male serum samples. Clinical Chemistry 60 510-517. (doi:10.1373/clinchem.2013.213363)

Hedlund PO, Damber JE, Hagerman I, Haukaas S, Henriksson P, Iversen P, Johansson R, Klarskov P, Lundbeck F, Rasmussen F, et al. 2008 Parenteral estrogen versus combined androgen deprivation in the treatment of metastatic prostatic cancer: part 2. Final evaluation of the Scandinavian Prostatic Cancer Group (SPCG) Study No. 5. Scandinavian Journal of Urology and Nephrology 42 220-229. (doi:10.1080/00365590801943274)

Henriksson P, Blombäck M, Bratt G, Edhag O \& Eriksson A 1986 Activators and inhibitors of coagulation and fibrinolysis in patients with prostatic cancer treated with oestrogen or orchidectomy. Thrombosis Research 44 783-791. (doi:10.1016/0049. 3848(86)90024-1)

Henriksson P, Blombäck M, Bratt G, Edhag O, Eriksson A \& Vesterqvist O 1989 Effects of oestrogen therapy and orchidectomy on coagulation and prostanoid synthesis in patients with prostatic cancer. Medical Oncology and Tumor Pharmacotherapy 6 219-225.

Henriksson P, Blombäck M, Eriksson A, Stege R \& Carlström K 1990 Effect of parenteral oestrogen on the coagulation system in patients with prostatic carcinoma. British Journal of Urology 65 282-285. (doi:10.1111/j.1464-410X.1990.tb14728.x)

Herrmann BL, Saller B, Janssen OE, Gocke P, Bockisch A, Sperling H, Mann K \& Broecker M 2002 Impact of estrogen replacement therapy in a male with congenital aromatase deficiency caused by a novel mutation in the CYP19 gene. Journal of Clinical Endocrinology and Metabolism 87 5476-5484. (doi:10.1210/jc.2002-020498) 
Huggins C 1967 Nobel prize lecture. Endocrine-induced regression of cancers. Cancer Research 27 1925-1930.

Huggins C \& Hodges CV 1941 Studies on prostatic cancer. I. The effect of castration, of estrogen and of androgen injection on serum phosphatases in metastatic carcinoma of the prostate. Cancer Research 1 293-297.

Jayasena CN, Comninos AN, Stefanopoulou E, Buckley A, Narayanaswamy S, Izzi-Engbeaya C, Abbara A, Ratnasabapathy R, Mogford J, Ng N, et al. 2015 Neurokinin B administration induces hot flushes in women. Scientific Reports 5 8466. (doi:10.1038/ srep08466)

Jones ME, Thorburn AW, Britt KL, Hewitt KN, Wreford NG, Proietto J, Oz OK, Leury BJ, Robertson KM, Yao S, et al. 2000 Aromatasedeficient (ArKO) mice have a phenotype of increased adiposity. PNAS 97 12735-12740. (doi:10.1073/pnas.97.23.12735)

Jones MEE, Boon WC, McInnes K, Maffei L, Carani C \& Simpson ER 2007 Recognizing rare disorders: aromatase deficiency. Nature Clinical Practice Endocrinology and Metabolism 3 414-421. (doi:10.1038/ ncpendmet0477)

Jones JM, Kohli M \& Loprinzi CL 2012 Androgen deprivation therapyassociated vasomotor symptoms. Asian Journal of Andrology 14 193-197. (doi:10.1038/aja.2011.101)

Juang PS, Peng S, Allehmazedeh K, Shah A, Coviello AD \& Herbst KL 2014 Testosterone with dutasteride, but not anastrazole, improves insulin sensitivity in young obese men: a randomized controlled trial. Journal of Sexual Medicine 11 563-573. (doi:10.1111/jsm.12368)

Karling P, Hammar M \& Varenhorst E 1994 Prevalence and duration of hot flushes after surgical or medical castration in men with prostatic carcinoma. Journal of Urology 152 1170-1173. (doi:10.1016/S00225347(17)32530-2)

Kelch RP, Jenner MR, Weinstein R, Kaplan SL \& Grumbach MM 1972 Estradiol and testosterone secretion by human, simian, and canine testes, in males with hypogonadism and in male pseudohermaphrodites with the feminizing testes syndrome. Journal of Clinical Investigation 51 824-830. (doi:10.1172/JCI106877)

Khosla S, Melton LJ \& Riggs BL 2001 Estrogens and bone health in men. Calcified Tissue International 69 189-192. (doi:10.1007/s00223-0011044-8)

Klotz L, Boccon-Gibod L, Shore ND, Andreou C, Persson B-E, Cantor P, Jensen J-K, Olesen TK \& Schröder FH 2008 The efficacy and safety of degarelix: a 12-month, comparative, randomized, open-label, parallel-group phase III study in patients with prostate cancer. BJU International 102 1531-1538. (doi:10.1111/j.1464-410X.2008.08183.x)

Komesaroff PA, Fullerton M, Esler MD, Dart A, Jennings G \& Sudhir K 2001 Low-dose estrogen supplementation improves vascular function in hypogonadal men. Hypertension 38 1011-1016. (doi:10.1161/hy1101.095006)

Lakshman KM, Kaplan B, Travison TG, Basaria S, Knapp PE, Singh AB, LaValley MP, Mazer NA \& Bhasin S 2010 The effects of injected testosterone dose and age on the conversion of testosterone to estradiol and dihydrotestosterone in young and older men. Journal of Clinical Endocrinology and Metabolism 95 3955-3964. (doi:10.1210/jc.2010-0102)

Langley RE, Cafferty FH, Alhasso AA, Rosen SD, Sundaram SK, Freeman SC, Pollock P, Jinks RC, Godsland IF, Kockelbergh R, et al. 2013 Cardiovascular outcomes in patients with locally advanced and metastatic prostate cancer treated with luteinising- hormonereleasing-hormone agonists or transdermal oestrogen: the randomised, phase 2 MRC PATCH trial. Lancet Oncology 14 306-316. (doi:10.1016/S1470-2045(13)70025-1)

Langley RE, Kynaston HG, Alhasso AA, Duong T, Paez EM, Jovic G, Scrase CD, Robertson A, Cafferty F, Welland A, et al. 2016 A randomised comparison evaluating changes in bone mineral density in advanced prostate cancer: luteinising hormone-releasing hormone agonists versus transdermal oestradiol. European Urology 69 1016-1025. (doi:10.1016/j.eururo.2015.11.030)
Lau K-M \& To K-F 2016 Importance of estrogenic signaling and its mediated eeceptors in prostate cancer. International Journal of Molecular Sciences 17 1434. (doi:10.3390/ijms17091434)

Leach DA, Powell SM \& Bevan CL 2016 New roles for nuclear receptors in prostate cancer. Endocrine-Related Cancer 23 T85-T108. (doi:10.1530/ERC-16-0319)

Leavy M, Trottmann M, Liedl B, Reese S, Stief C, Freitag B, Baugh J, Spagnoli G \& Kölle S 2017 Effects of elevated $\beta$-estradiol levels on the functional morphology of the testis - new insights. Scientific Reports 7 39931. (doi:10.1038/srep39931)

Leuprolide Study Group 1984 Leuprolide versus diethylstilbestrol for metastatic prostate cancer. New England Journal of Medicine $\mathbf{3 1 1}$ 1281-1286. (doi:10.1056/NEJM198411153112004)

Longcope C, Kato T \& Horton R 1969 Conversion of blood androgens to estrogens in normal adult men and women. Journal of Clinical Investigation 48 2191-2201. (doi:10.1172/JCI106185)

Lu-Yao G, Stukel TA \& Yao S-L 2004 Changing patterns in competing causes of death in men with prostate cancer: a population based study. Journal of Urology 171 2285-2290. (doi:10.1097/01. ju.0000127740.96006.1a)

MacDonald PC, Madden JD, Brenner PF, Wilson JD \& Siiteri PK 1979 Origin of estrogen in normal men and in women with testicular feminization. Journal of Clinical Endocrinology and Metabolism 49 905-916. (doi:10.1210/jcem-49-6-905)

Marcus R, Leary D, Schneider DL, Shane E, Favus M \& Quigley CA 2000 The contribution of testosterone to skeletal development and maintenance: lessons from the androgen insensitivity syndrome. Journal of Clinical Endocrinology and Metabolism 85 1032-1037. (doi:10.1210/jcem.85.3.6428)

Matousek RH \& Sherwin BB 2010 A randomized controlled trial of addback estrogen or placebo on cognition in men with prostate cancer receiving an antiandrogen and a gonadotropin-releasing hormone analog. Psychoneuroendocrinology 35 215-225. (doi:10.1016/j. psyneuen.2009.06.012)

McGinty HL, Phillips KM, Jim HSL, Cessna JM, Asvat Y, Cases MG, Small BJ \& Jacobsen PB 2014 Cognitive functioning in men receiving androgen deprivation therapy for prostate cancer: a systematic review and meta-analysis. Supportive Care in Cancer 22 2271-2280. (doi:10.1007/s00520-014-2285-1)

Melner MH \& Abney TO 1980 The direct effect of 17 beta-estradiol on LH-stimulated testosterone production in hypophysectomized rats. Journal of Steroid Biochemistry 13 203-210. (doi:10.1016/00224731(80)90193-4)

Miftakhova R, Hedblom A, Semenas J, Robinson B, Simoulis A, Malm J, Rizvanov A, Heery DM, Mongan NP, Maitland NJ, et al. 2016 Cyclin $\mathrm{A} 1$ and P450 aromatase promote metastatic homing and growth of stem-like prostate cancer cells in the bone marrow. Cancer Research 76 2453-2464. (doi:10.1158/0008-5472.CAN-15-2340)

Mikkola A, Aro J, Rannikko S, Ruutu M \& Finnprostate Group 2007 Tenyear survival and cardiovascular mortality in patients with advanced prostate cancer primarily treated by intramuscular polyestradiol phosphate or orchiectomy. Prostate 67 447-455. (doi:10.1002/ pros.20547)

Miller JI \& Ahmann FR 1992 Treatment of castration-induced menopausal symptoms with low dose diethylstilbestrol in men with advanced prostate cancer. Urology 40 499-502. (doi:10.1016/00904295(92)90401-h)

Miyajima M, Kusuhara H, Takahashi K, Takashima T, Hosoya T, Watanabe Y \& Sugiyama Y 2013 Investigation of the effect of active efflux at the blood-brain barrier on the distribution of nonsteroidal aromatase inhibitors in the central nervous system. Journal of Pharmaceutical Sciences 102 3309-3319. (doi:10.1002/ jps.23600)

Morishima A, Grumbach MM, Simpson ER, Fisher C \& Qin K 1995 Aromatase deficiency in male and female siblings caused by a novel mutation and the physiological role of estrogens. Journal of Clinical

Published by Bioscientifica Ltc. 
Endocrinology and Metabolism 80 3689-3698. (doi:10.1210/ jcem.80.12.8530621)

Morselli E, Santos RS, Criollo A, Nelson MD, Palmer BF \& Clegg DJ 2017 The effects of oestrogens and their receptors on cardiometabolic health. Nature Reviews Endocrinology 13 352-364. (doi:10.1038/ nrendo.2017.12)

Mottet N, Bellmunt J, Bolla M, Briers E, Cumberbatch MG, De Santis M, Fossati N, Gross T, Henry AM, Joniau S, et al. 2017 EAU-ESTRO-SIOG guidelines on prostate cancer. Part 1: screening, siagnosis, and local treatment with curative intent. European Urology 71 618-629. (doi:10.1016/j.eururo.2016.08.003)

Nelson HD 2004 Postmenopausal estrogen for treatment of hot flashes: clinical applications. JAMA 291 1621-1625. (doi:10.1001/ jama.291.13.1621)

Nelson CJ, Lee JS, Gamboa MC \& Roth AJ 2008 Cognitive effects of hormone therapy in men with prostate cancer: a review. Cancer 113 1097-1106. (doi:10.1002/cncr.23658)

Nesbit RM \& Baum WC 1950 Endocrine control of prostatic carcinoma; clinical and statistical survey of 1818 cases. JAMA 143 1317-1320. (doi:10.1001/jama.1950.02910500019005)

Norman G, Dean ME, Langley RE, Hodges ZC, Ritchie G, Parmar MKB, Sydes MR, Abel P \& Eastwood AJ 2008 Parenteral oestrogen in the treatment of prostate cancer: a systematic review. British Journal of Cancer 98 697-707. (doi:10.1038/sj.bjc.6604230)

Ockrim JL, Lalani E-N, Laniado ME, Carter SSC \& Abel PD 2003 Transdermal estradiol therapy for advanced prostate cancer - forward to the past? Journal of Urology 169 1735-1737. (doi:10.1097/01. ju.0000061024.75334.40)

Ockrim JL, Lalani E-N, Kakkar AK \& Abel PD 2005 Transdermal estradiol therapy for prostate cancer reduces thrombophilic activation and protects against thromboembolism. Journal of Urology 174 527-533. (doi:10.1097/01.ju.0000165567.99142.1f)

Ockrim J, Lalani E-N \& Abel P 2006 Therapy insight: parenteral estrogen treatment for prostate cancer - a new dawn for an old therapy. Nature Clinical Practice Oncology 3 552-563. (doi:10.1038/ ncponc0602)

Ogawa S, Chester AE, Hewitt SC, Walker VR, Gustafsson JA, Smithies O, Korach KS \& Pfaff DW 2000 Abolition of male sexual behaviors in mice lacking estrogen receptors alpha and beta (alpha beta ERKO). PNAS 97 14737-14741. (doi:10.1073/pnas.250473597)

Pagliarulo V, Bracarda S, Eisenberger MA, Mottet N, Schröder FH, Sternberg CN \& Studer UE 2012 Contemporary role of androgen deprivation therapy for prostate cancer. European Urology 61 11-25. (doi:10.1016/j.eururo.2011.08.026)

Paternoster L, Lorentzon M, Lehtimäki T, Eriksson J, Kähönen M, Raitakari O, Laaksonen M, Sievänen H, Viikari J, Lyytikäinen L-P, et al. 2013 Genetic determinants of trabecular and cortical volumetric bone mineral densities and bone microstructure. PLoS Genetics 9 e1003247. (doi:10.1371/journal.pgen.1003247)

Powers MS, Schenkel L, Darley PE, Good WR, Balestra JC \& Place VA 1985 Pharmacokinetics and pharmacodynamics of transdermal dosage forms of 17 beta-estradiol: comparison with conventional oral estrogens used for hormone replacement. American Journal of Obstetrics and Gynecology 152 1099-1106. (doi:10.1016/0002-9378(85)90569-1)

Prague JK, Roberts RE, Comninos AN, Clarke S, Jayasena CN, Nash Z, Doyle C, Papadopoulou DA, Bloom SR, Mohideen P, et al. 2017 Neurokinin 3 receptor antagonism as a novel treatment for menopausal hot flushes: a phase 2, randomised, double-blind, placebo-controlled trial. Lancet 389 1809-1820. (doi:10.1016/S0140-6736(17)30823-1)

Radu A, Pichon C, Camparo P, Antoine M, Allory Y, Couvelard A, Fromont G, Hai MTV \& Ghinea N 2010 Expression of folliclestimulating hormone receptor in tumor blood vessels. New England Journal of Medicine 363 1621-1630. (doi:10.1056/NEJMoa1001283)

Rahman HP, Hofland J \& Foster PA 2016 In touch with your feminine side: how oestrogen metabolism impacts prostate cancer. EndocrineRelated Cancer 23 R249-R266. (doi:10.1530/ERC-16-0118)
Rance NE, Dacks PA, Mittelman-Smith MA, Romanovsky AA \& KrajewskiHall SJ 2013 Modulation of body temperature and LH secretion by hypothalamic KNDy (kisspeptin, neurokinin B and dynorphin) neurons: a novel hypothesis on the mechanism of hot flushes. Frontiers in Neuroendocrinology 34 211-227. (doi:10.1016/j.yfrne.2013.07.003)

Razandi M, Pedram A, Merchenthaler I, Greene GL \& Levin ER 2004 Plasma membrane estrogen receptors exist and functions as dimers. Molecular Endocrinology 18 2854-2865. (doi:10.1210/me.2004-0115)

Resnick SM, Matsumoto AM, Stephens-Shields AJ, Ellenberg SS, Gill TM, Shumaker SA, Pleasants DD, Barrett-Connor E, Bhasin S, Cauley JA, et al. 2017 Testosterone treatment and cognitive function in older men with low testosterone and age-associated memory impairment. JAMA 317 717-727. (doi:10.1001/jama.2016.21044)

Revankar CM, Cimino DF, Sklar LA, Arterburn JB \& Prossnitz ER 2005 A transmembrane intracellular estrogen receptor mediates rapid cell signaling. Science 307 1625-1630. (doi:10.1126/science.1106943)

Risbridger GP, Ellem SJ \& McPherson SJ 2007 Estrogen action on the prostate gland: a critical mix of endocrine and paracrine signaling. Journal of Molecular Endocrinology 39 183-188. (doi:10.1677/JME-070053)

Risbridger GP, Davis ID, Birrell SN \& Tilley WD 2010 Breast and prostate cancer: more similar than different. Nature Reviews Cancer 10 205-212. (doi:10.1038/nrc2795)

Robertson CN, Roberson KM, Padilla GM, O’Brien ET, Cook JM, Kim CS \& Fine RL 1996 Induction of apoptosis by diethylstilbestrol in hormone-insensitive prostate cancer cells. Journal of the National Cancer Institute 88 908-917. (doi:10.1093/jnci/88.13.908)

Ryan CJ, Smith MR, de Bono JS, Molina A, Logothetis CJ, de Souza P, Fizazi K, Mainwaring P, Piulats JM, Ng S, et al. 2013 Abiraterone in metastatic prostate cancer without previous chemotherapy. New England Journal of Medicine 368 138-148. (doi:10.1056/NEJMoa1209096)

Santen RJ, Demers LM, Max DT, Smith J, Stein BS \& Glode LM 1984 Long term effects of administration of a gonadotropin-releasing hormone superagonist analog in men with prostatic carcinoma. Journal of Clinical Endocrinology and Metabolism 58 397-400. (doi:10.1210/jcem-58-2-397)

Sasano H, Uzuki M, Sawai T, Nagura H, Matsunaga G, Kashimoto O \& Harada N 1997 Aromatase in human bone tissue. Journal of Bone and Mineral Research 12 1416-1423. (doi:10.1359/jbmr.1997.12.9.1416)

Schally AV, Arimura A, Kastin AJ, Matsuo H, Baba Y, Redding TW, Nair RM, Debeljuk L \& White WF 1971 Gonadotropin-releasing hormone: one polypeptide regulates secretion of luteinizing and folliclestimulating hormones. Science 173 1036-1038. (doi:10.1126/ science.173.4001.1036)

Scher HI, Fizazi K, Saad F, Taplin ME, Sternberg CN, Miller K, de Wit R, Mulders P, Chi KN, Shore ND, et al. 2012 Increased survival with enzalutamide in prostate cancer after chemotherapy. New England Journal of Medicine 367 1187-1197. (doi:10.1056/NEJMoa1207506)

Scherr D, Pitts WR \& Vaughn ED 2002 Diethylstilbesterol revisited: androgen deprivation, osteoporosis and prostate cancer. Journal of Urology 167 535-538. (doi:10.1016/S0022-5347(01)69080-3)

Schoultz von B, Carlström K, Collste L, Eriksson A, Henriksson P, Pousette A \& Stege R 1989 Estrogen therapy and liver function metabolic effects of oral and parenteral administration. Prostate 14 389-395. (doi:10.1002/pros.2990140410)

Schulz P, Bauer HW, Brade WP, Keller A \& Fittler F 1988 Evaluation of the cytotoxic activity of diethylstilbestrol and its mono- and diphosphate towards prostatic carcinoma cells. Cancer Research $\mathbf{4 8}$ 2867-2870.

Schulz P, Link TA, Chaudhuri L \& Fittler F 1990 Role of the mitochondrial bc1-complex in the cytotoxic action of diethylstilbestrol-diphosphate toward prostatic carcinoma cells. Cancer Research 50 5008-5012.

Seeman E \& Martin TJ 2015 Co-administration of antiresorptive and anabolic agents: a missed opportunity. Journal of Bone and Mineral Research 30 753-764. (doi:10.1002/jbmr.2496) 
Seidenfeld J, Samson DJ, Hasselblad V, Aronson N, Albertsen PC, Bennett CL \& Wilt TJ 2000 Single-therapy androgen suppression in men with advanced prostate cancer: a systematic review and metaanalysis. Annals of Internal Medicine 132 566-577. (doi:10.7326/00034819-132-7-200004040-00009)

Shahinian VB, Kuo Y-F, Freeman JL \& Goodwin JS 2005 Risk of fracture after androgen deprivation for prostate cancer. New England Journal of Medicine 352 154-164. (doi:10.1056/NEJMoa041943)

Shahinian VB, Kuo Y-F, Freeman JL \& Goodwin JS 2006 Risk of the 'androgen deprivation syndrome' in men receiving androgen deprivation for prostate cancer. Archives of Internal Medicine 166 465-471. (doi:10.1001/archinte.166.4.465)

Shao Y-H, Moore DF, Shih W, Lin Y, Jang TL \& Lu-Yao GL 2013 Fracture after androgen deprivation therapy among men with a high baseline risk of skeletal complications. BJU International 111 745-752. (doi:10.1111/j.1464-410X.2012.11758.x)

Sharifi R, Bruskewitz RC, Gittleman MC, Graham SD, Hudson PB \& Stein B 1996 Leuprolide acetate $22.5 \mathrm{mg}$ 12-week depot formulation in the treatment of patients with advanced prostate cancer. Clinical Therapeutics 18 647-657. (doi:10.1016/S0149-2918(96)80215-3)

Sharifi N, Gulley JL \& Dahut WL 2005 Androgen deprivation therapy for prostate cancer. JAMA 294 238-244. (doi:10.1001/jama.294.2.238)

Shulman LP, Yankov V \& Uhl K 2002 Safety and efficacy of a continuous once-a-week 17beta-estradiol/levonorgestrel transdermal system and its effects on vasomotor symptoms and endometrial safety in postmenopausal women: the results of two multicenter, doubleblind, randomized, controlled trials. Menopause 9 195-207. (doi:10.1097/00042192-200205000-00008)

Simon JA, Bouchard C, Waldbaum A, Utian W, Zborowski J \& Snabes MC 2007 Low dose of transdermal estradiol gel for treatment of symptomatic postmenopausal women: a randomized controlled trial. Obstetrics and Gynecology 109 588-596. (doi:10.1097/01.AOG.0000254160.62588.41)

Simpson ER 2003 Sources of estrogen and their importance. Journal of Steroid Biochemistry and Molecular Biology 86 225-230. (doi:10.1016/ S0960-0760(03)00360-1)

Smith JA 1994 A prospective comparison of treatments for symptomatic hot flushes following endocrine therapy for carcinoma of the prostate. Journal of Urology 152 132-134. (doi:10.1016/s00225347(17)32835-5)

Smith EP, Boyd J, Frank GR, Takahashi H, Cohen RM, Specker B, Williams TC, Lubahn DB \& Korach KS 1994 Estrogen resistance caused by a mutation in the estrogen-receptor gene in a man. New England Journal of Medicine 331 1056-1061. (doi:10.1056/NEJM199410203311604)

Smith MR, Finkelstein JS, McGovern FJ, Zietman AL, Fallon MA, Schoenfeld DA \& Kantoff PW 2002a Changes in body composition during androgen deprivation therapy for prostate cancer. Journal of Clinical Endocrinology and Metabolism 87 599-603. (doi:10.1210/ jcem.87.2.8299)

Smith MR, Kaufman D, George D, Oh WK, Kazanis M, Manola J \& Kantoff PW $2002 b$ Selective aromatase inhibition for patients with androgen-independent prostate carcinoma. Cancer 95 1864-1868. (doi:10.1002/cncr.10844)

Smith YR, Love T, Persad CC, Tkaczyk A, Nichols TE \& Zubieta J-K 2006 Impact of combined estradiol and norethindrone therapy on visuospatial working memory assessed by functional magnetic resonance imaging. Journal of Clinical Endocrinology and Metabolism 91 4476-4481. (doi:10.1210/jc.2006-0907)

Song WC 2001 Biochemistry and reproductive endocrinology of estrogen sulfotransferase. Annals of the New York Academy of Sciences 948 43-50. (doi:10.1111/j.1749-6632.2001.tb03985.x)

Spetz AC, Pettersson B, Varenhorst E, Theodorsson E, Thorell LH \& Hammar M 2001 Momentary increase in plasma calcitonin gene- related peptide is involved in hot flashes in men treated with castration for carcinoma of the prostate. Journal of Urology 166 1720-1723. (doi:10.1016/S0022-5347(05)65660-1)

Spry NA, Taaffe DR, England PJ, Judge JS, Stephens DA,

Peddle-McIntyre C, Baker MK, Newton RU \& Galvão DA 2013 Long-term effects of intermittent androgen suppression therapy on lean and fat mass: a 33-month prospective study. Prostate Cancer and Prostatic Diseases 16 67-72. (doi:10.1038/pcan.2012.33)

Stege R, Fröhlander N, Carlström K, Pousette A \& Schoultz von B 1987 Steroid-sensitive proteins, growth hormone and somatomedin C in prostatic cancer: effects of parenteral and oral estrogen therapy. Prostate 10 333-338. (doi:10.1002/pros.2990100407)

Taxel P, Kennedy DG, Fall PM, Willard AK, Clive JM \& Raisz LG 2001 The effect of aromatase inhibition on sex steroids, gonadotropins, and markers of bone turnover in older men. Journal of Clinical Endocrinology and Metabolism 86 2869-2874. (doi:10.1210/jcem.86.6.7541)

Taxel P, Fall PM, Albertsen PC, Dowsett RD, Trahiotis M, Zimmerman J, Ohannessian C \& Raisz LG 2002 The effect of micronized estradiol on bone turnover and calciotropic hormones in older men receiving hormonal suppression therapy for prostate cancer. Journal of Clinical Endocrinology and Metabolism 87 4907-4913. (doi:10.1210/jc.2002020539)

Taxel P, Stevens MC, Trahiotis M, Zimmerman J \& Kaplan RF 2004 The effect of short-term estradiol therapy on cognitive function in older men receiving hormonal suppression therapy for prostate cancer. Journal of the American Geriatrics Society 52 269-273. (doi:10.1111/j.1532-5415.2004.52067.x)

Taylor AP, Lee H, Webb ML, Joffe H \& Finkelstein JS 2016 Effects of testosterone and estradiol deficiency on vasomotor symptoms in hypogonadal men. Journal of Clinical Endocrinology and Metabolism 101 3479-3486. (doi:10.1210/jc.2016-1612)

Torti FM 1984 Hormonal therapy for prostate cancer. New England Journal of Medicine 311 1313-1314. (doi:10.1056/ NEJM198411153112010)

Townsend PT, Dyer GI, Young O, Whitehead MI \& Collins WP 1981 The absorption and metabolism of oral oestradiol, oestrone and oestriol. British Journal of Obstetrics and Gynaecology 88 846-852. (doi:10.1111/j.1471-0528.1981.tb01312.x)

van den Beld AW, de Jong FH, Grobbee DE, Pols HA \& Lamberts SW 2000 Measures of bioavailable serum testosterone and estradiol and their relationships with muscle strength, bone density, and body composition in elderly men. Journal of Clinical Endocrinology and Metabolism 85 3276-3282. (doi:10.1210/jcem.85.9.6825)

Vandenput L, Mellström D, Karlsson MK, Orwoll E, Labrie F, Ljunggren O \& Ohlsson C 2010 Serum estradiol is associated with lean mass in elderly Swedish men. European Journal of Endocrinology 162 737-745. (doi:10.1530/EJE-09-0696)

Vandenput L, Lorentzon M, Sundh D, Nilsson ME, Karlsson MK, Mellström D \& Ohlsson C 2014 Serum estradiol levels are inversely associated with cortical porosity in older men. Journal of Clinical Endocrinology and Metabolism 99 E1322-E1326. (doi:10.1210/jc.2014-1319)

Wibowo E, Schellhammer P \& Wassersug RJ 2011 Role of estrogen in normal male function: clinical implications for patients with prostate cancer on androgen deprivation therapy. Journal of Urology 185 17-23. (doi:10.1016/j.juro.2010.08.094)

Yeap BB, Alfonso H, Chubb SAP, Handelsman DJ, Hankey GJ, Norman PE \& Flicker L 2012 Reference ranges and determinants of testosterone, dihydrotestosterone, and estradiol levels measured using liquid chromatography-tandem mass spectrometry in a population-based cohort of older men. Journal of Clinical Endocrinology and Metabolism 97 4030-4039. (doi:10.1210/ jc.2012-2265)

Received in final form 20 June 2017

Accepted 22 June 2017

Accepted Preprint published online 30 June 2017

Published by Bioscientifica Ltd. 